\title{
Drie eeue van militêre diensplig in Suid-Afrika
}

\author{
Lt kdr E.M. Meyers*
}

The history of National Service in South Africa goes back more than $\mathbf{3 0 0}$ years to the arrival of the first settlers at the Cape and the necessity to protect life and property. This was the start of the Commando system that the pioneers took with them on their trek to the Orange Free State, Natal and the Transvaal. The development of this system of defence is traced back and discussed in detail from its origin to what it has become today, emphasizing both the advantages and the problem areas. All aspects of National Service is meticulously attended to, inter alia the role of women and Non-Whites and conculding with the role that immigrants have to fulfil as far as National Service is concerned.

\section{Inleiding}

Militêre diensplig hier te lande is so oud soos die volksplanting self. In die lig van die geskiedenis waar een of ander bedreiging telkens deur ' $n$ volksleër die hoof gebied moes word, kan militêre diensplig nie net as ' $n$ volksverantwoordelikheid nie, maar ook as 'n burgerreg beskou word.

Weens onseker en onveilige lewensomstandighede is die nedersetting aan die Kaap meer as 300 jaar gelede al genoop om die wapen op te neem en hulle goed en bloed te verdedig. Plunderende Hottentotte en Boesmans het die Vryburgers van die 17 de en 18de eeue op hulle verafgeleë plase in die binneland geterroriseer. Netso het die latere ontmoeting van migrerende swart stamme en blanke trekkers in die OosKaap tot etlike bloedige grensoorloë gelei.

Die Blanke veeboer het gevolglik vroeg reeds ' $n$ unieke verdedigingstelsel van persoonlike diensplig in die lewe geroep. Elke manlike burger is medeverantwoordelik gemaak vir die beveiliging van sy gebied. Dit was die begin van die kommandostelsel wat later met soveel welslae in die Suid-Afrikaanse geskiedenis toegepas is.

Die Trekkers het in hul noordwaartse trek na die Oranje-Vrystaat, Natal en Transvaal die kommandostelsel met hulle saamgeneem. In die nuwe gevaarlike wêreld moes elkeen sy deel bydra tot die vestiging van Blanke beskawing en die verwesenliking van ' $n$ vryheidsideaal. Tot aan die einde van die Tweede Vryheidsoorlog is die kommandostelsel grotendeels deur die Republieke gebruik en met Uniewording is die beginsel van persoonlike diensplig in die Verdedigingswet van 1912 ingebou. Met die uitbreek van die twee Wêreldoorloë het Suid-Afrika as Statebondsland aktief tot die stryd toegetree.

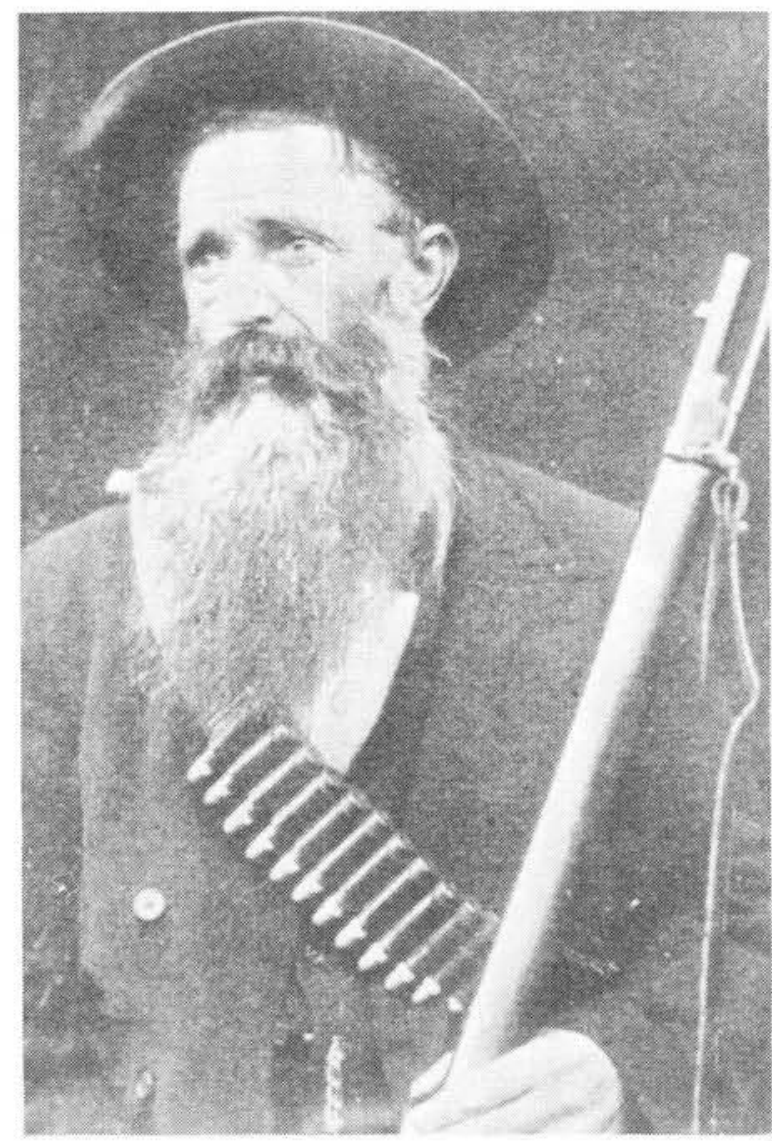

Sedert Republiekwording het die terroristiese bedreiging op ons landsgrense asook in die stede self toegeneem en by verskeie geleenthede is die vereistes van diensplig aangepas om die bedreiging die hoof te bied. In hierdie artikel word die ontwikkeling van militêre diensplig in Suid-Afrika oor die afgelope drie eeue oorsigtelik in oënskou geneem. 


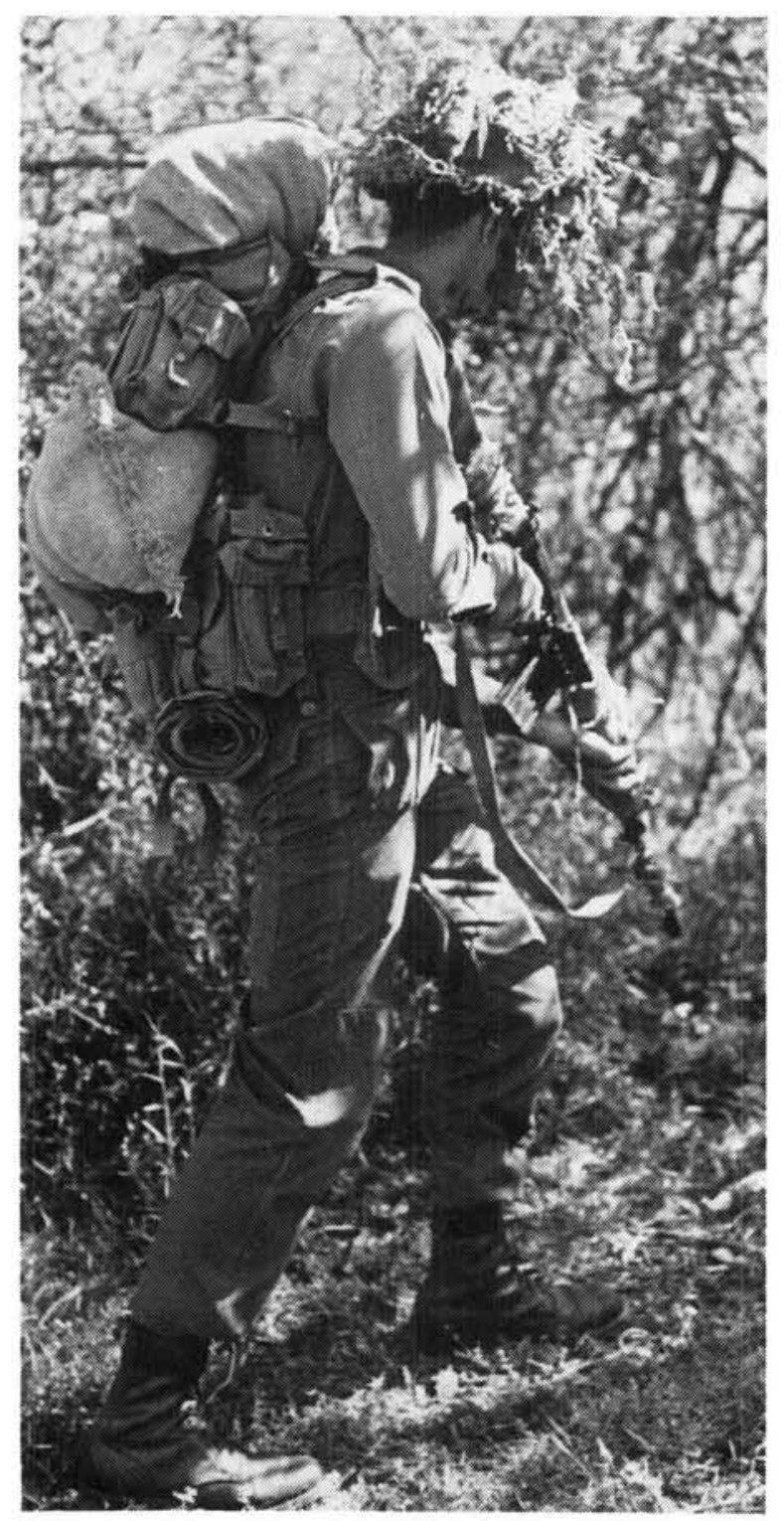

'n Dlenspllgtige verken dle terrein tydens 'n veldoefening

\section{Vryburger-fase}

Die grondslae van 'n plaaslike verdedigingstelsel is gedurende die bewind van die Nederlandse Oos-Indiese Kompanjie aan die Kaap gelê. In 1658 is al die weerbare Vryburgers in 'n skutterskompanie wat op dieselfde grondslag as gewone soldate georganiseer is, gevorm. Die belangrikste oorweging waarom Vryburgers met militêre diens belas is, was uit selfverdediging. Reeds in 1659 het die eerste Boerekommando bestaande uit sewe burgers en gewapen "meestal met vorcken ende 2-3 met skietgeweer" teen die Hottentotte opgetrek.

$\mathrm{Na}$ gelang die Blanke bevolking verder in die binneland ingetrek het, het die kommandostelsel al hoe meer ontwikkel. Die Kaapse regering het eers amptelike kommando's onder leiding van kompanjie offisiere uitgestuur, maar nadat burgerdiens verpligtend vir alle burgers tussen die ouderdomme 16 en 60 jaar gemaak is, het die pligte op die burgers oorgegaan. Alle jongelinge wat uit die Kompanjie se diens ontslaan is, moes hulself binne drie maande by die kavalerie of by die infanterie - die onderskeie afdelings van die burgermilisie - laat inskrywe.

Militêre oefening was aanvanklik vrywillig maar is so vroeg as 1672 al verpligtend gemaak. In 1687 is bepaal dat al die burgers van Kaapstad minstens een keer per jaar ten volle gewapen moes optrek om agt dae in die "wapenhandel te oefen". Niemand kon sonder 'n wettige rede van die optrek of parade wegbly nie. Verdedigingsorders is dus so vroeg as die tyd van die Vryburgers uitgevaardig om die manlike bevolking paraat te hou.

Elke seun in die grensdistrikte het feitlik met die geweer in die hand opgegroei en is van kleins af geleer om sy persoon en die familiebesit te help verdedig. Van byna die aanvang van die $18 d e$ eeu af was veeboere op eie kragte aangewese in die verdediging teen die Boesmans en later teen Swartes. So het die kommandostelsel as ' $n$ nasionale instelling ontwikkel. Suiwer burgerkommando's het weldra die plek van die vroeëre regeringskommando's ingeneem.

Gedurende die herhaalde grensoorloë van die negentiende eeu is die burgerkommando's opgeroep om saam met die Britse eenhede te dien en om hierdie rede het die kommandostelsel bly voortbestaan.

\section{Voortrekker-tydperk}

Met hul trek na die binneland het die Voortrekkers hul tradisionele kommandostelsel van persoonlike diensplig met hulle meegeneem en dit in hul stryd teen die binnelandse swart stamme toegepas.

In sy bekende Manifes het Retief onderneem: "Ons sal geen volk molesteer en aan niemand die geringste eiendom ontneem nie, maar as ons aangeval word, sal ons ten volle geregtig wees om ons persoon en ons eiendom te verdedig tot die uiterste toe teen enige vyand."

\section{Kommandostelsel in die Vrystaat}

Die burger-kommando's was natuurlik die pri- 
mêre en trouens die enigste verdedigingsmiddel waaroor die staat beskik het. Die kommandostelsel is gaandeweg op vaste grondslag geplaas en binne 'n paar dae nadat die grondwet aangeneem is, het die Vrystaatse Volksraad op 8 April 1854 besluit om die Burger- of Commandowet deur te voer.

Die pligte van die veldkornette is nou duidelik uiteengesit, aldus Swemmer in sy werk Geskiedenis van die Vrystaatse Artillerie. Hulle het die reg gehad om op bevel van die President, burgers tot kommandodiens op te roep. Die veldkornette kon ook wapens, osse en perde en die nodige provisie vir diens kommandeer. Elke gesonde manspersoon tussen 16 en 60 jaar was verplig om burgerdiens te doen en indien hy voldoende bemiddeld was, moes hy homself met perd, saal, geweer en wapens uitrus.

Elke drie tot vier maande sou vrywilligers op een of ander plek in hul wyk vergader om "sodanige oefeninge met wapens uit te voer". Vir die bekamping van veediewery en die smokkelhandel in wapens, het president Boshof die behoefte aan 'n grenswag of berede polisiemag geïdentifiseer.

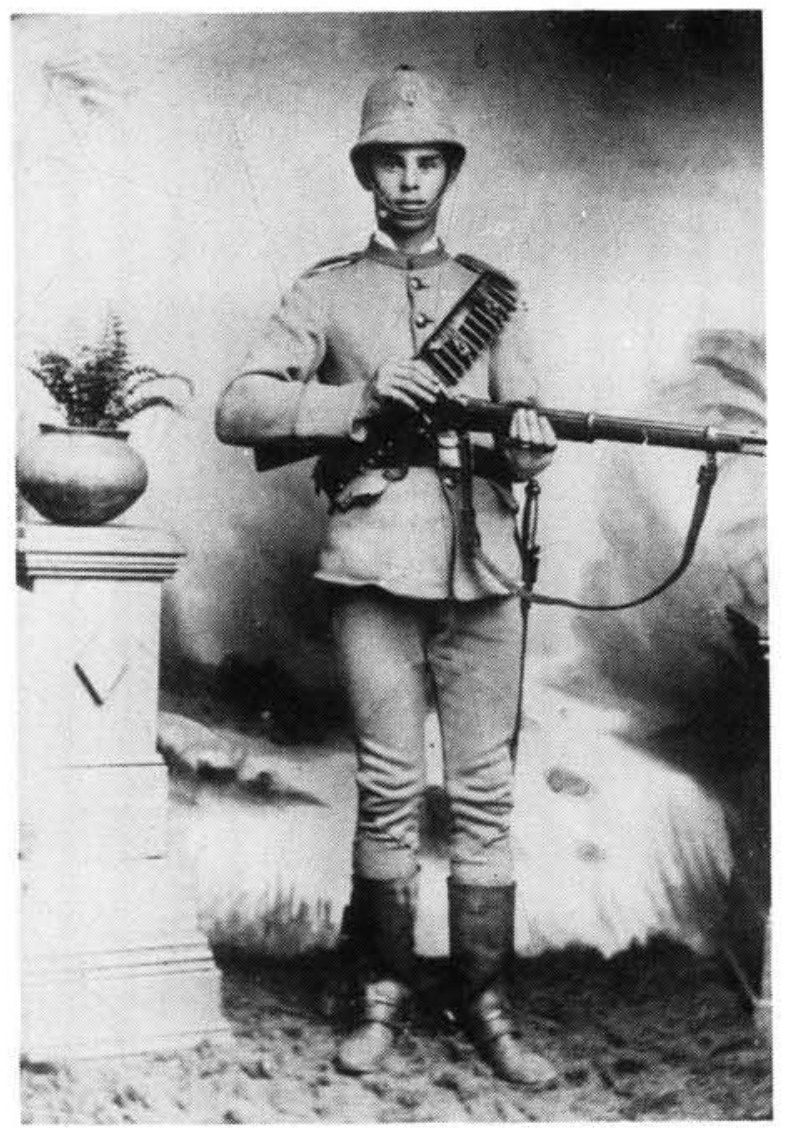

'n Manskap van dle Transvaalse Staatsartillerie In dle tweede helfte van dle 19de eeu, (SAW Arglefbewaarplek nr 700017192)

\section{Die opbou van die ZAR tot 1870}

In die Zuid-Afrikaansche Republiek het die grootste organisatoriese werk op die veldkornette neergekom, aldus Van Jaarsveld in sy werk Die Veldkornet en sy aandeel in die opbou van die SA Republiek tot 1870 . Om kontrole te hou is burgerlyste opgestel wat die name bevat het van al die diensdoenende manskappe tussen die ouderdomme 16 en 60 jaar.

$\mathrm{Na} 1858$ het enkele Veldkornette hulle burgers ooreenkomstig die drie klasse stelsel in groepe van 16-30 jaar, 30-45 jaar en 45-60 jaar verdeel. Hierby kom nog die lys van burgers bo 60 jaar en een vir invalides. Jaarliks is seuns wat die ouderdom van 16 bereik het, as dienspligtige burgers ingeskrywe. Sekere kategorieë burgers is van krygsdiens vrygestel, maar ingeval van uiters dringende landsgevaar wanneer krygswet afgekondig is, was daar geen uitsondering nie. By grootskaalse onwilligheid van die burgers om op kommando te gaan, het die President die "krygswet" afgekondig waardeur veldkornette almal moes oproep met swaar strawwe vir diegene wat nie daaraan gehoor gegee het nie.

\section{Eerste Vryheidsoorlog}

Afgesien van swart stamme se opstande waarin Boerekommando's in die Zuid-Afrikaansche Republiek betrokke was, het die Eerste Vryheidsoorlog na die anneksasie van Transvaal die kommandostelsel vir die eerste maal werklik beproef. Op 27 Februarie 1881 het die Boere die finale en gevierde Slag van Amajuba gelewer, waarin die Britte verslaan is en wat die oorlog beëindig het.

\section{Die Vrystaatse Republiek na die Eerste Vryheidsoorlog}

Die Vrystaatse Volksraad het in 1897 die nodige wysigings aan die kommandowet aangebring om aan die vereistes van nadere samewerking met Transvaal te voldoen. Hoewel 'n Vrystaatse kommando wat tot steun van die ZAR opgeroep kon word, onder sy eie offisiere sou dien, sou die opperbevel by die Kommandant-generaal van die ZAR berus. Die vrede in 'n gesamentlike oorlog sou alleen met toestemming van beide partye gesluit kon word. Tot aan die einde van die stryd teen Brittanje was die Republieke op hulle eie kragte aangewese. 


\section{Tweede Vryheidsoorlog (1899-1902)}

Ofskoon instellings soos die Transvaalse Staatsartillerie met die uitbreek van die oorlog in 1899 bestaan het, sou die Kommandostelsel die grondslag vir gewapende verset vorm. Deur die omstandighede van die Tweede Vryheidsoorlog was daar later nie net weerbare manne by die kommando's nie, maar selfs seuns van agt en nege jaar en bejaardes van oor die sewentig. In ronde getalle uitgedruk kon die beskikbare burgers op sowat 30000 Transvalers en 20000 Vrystaters gestel word met nog 2000 vrywilligers uit die twee Britse kolonies altesaam sowat 52000 man tussen 16 en 60 jaar van wie hoogstens 35000 in Oktober 1899 bewapen kon word. Gedurende die oorlog is hulle verder aangevul deur vrywilligers vanuit sommige Europese lande.
Teen die einde van 1900 het die twee Republieke die stryd op 'n guerrilla-grondslag voortgesit deur beweeglike berede kommando's sonder artillerie en gesofistikeerde kommunikasielyne. Hierdie kommando's het in hul eie gebiede opgetree, iets wat in die lig van die Britse opmars nie altyd moontlik was nie.

\section{Jare 1902-1912}

$\mathrm{Na}$ die Tweede Vryheidsoorlog het die Britse vrywilligerstelsel ook sy kop in die kolonies en in Transvaal begin uitsteek. Die tradisionele kommandostelsel in die noorde is afgeskaf en so is ' $n$ verpligte diens beëindig. Die vrywilligerstelsel van die jare 1902-1912 het geen ingang in die Oranjerivier-kolonie gevind nie, maar in Transvaal is die "Transvaal Volunteer"-organisasie

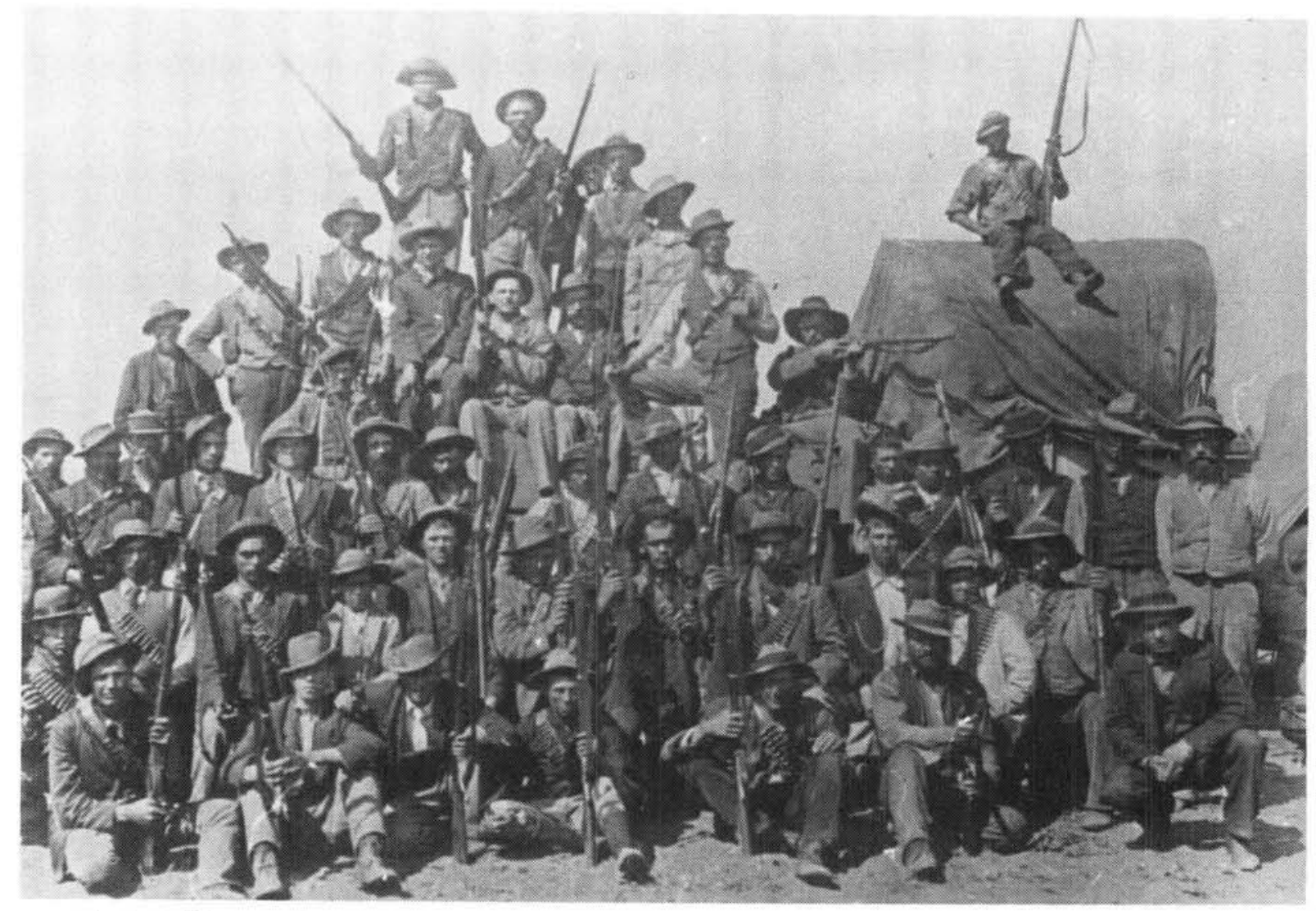

'n Aantal Boere op kommando tydens die Tweede Vryheidsoorlog. (SAW Argiefbewaarplek - nr 700001398)

Die Boeremagte het ' $n$ agterstand gehad aangesien geen enkele kommando behoorlik toegerus was nie. Daarby was die weerbare mannekrag onopgeleide burgerlikes met byna geen krygservaring behalwe veldtogte teen swart stamme nie. Dit was 'n volksleër waarvan die swakhede duidelik na vore gekom het en veral die gebrek aan militêre dissipline. daargestel. Wat Natal betref, het die Milisiewet in 1903 bepaal dat die sterkte, indien nodig, deur loting aangevul sou word.

In 1909 het brig-genl C.F. Beyers algemene diensplig op 'n konferensie van die Suid-Afrikaanse Vroue-Federasie bepleit en toe in 1911 aanstaltes gemaak is om ' $n$ verdedigingswet vir 


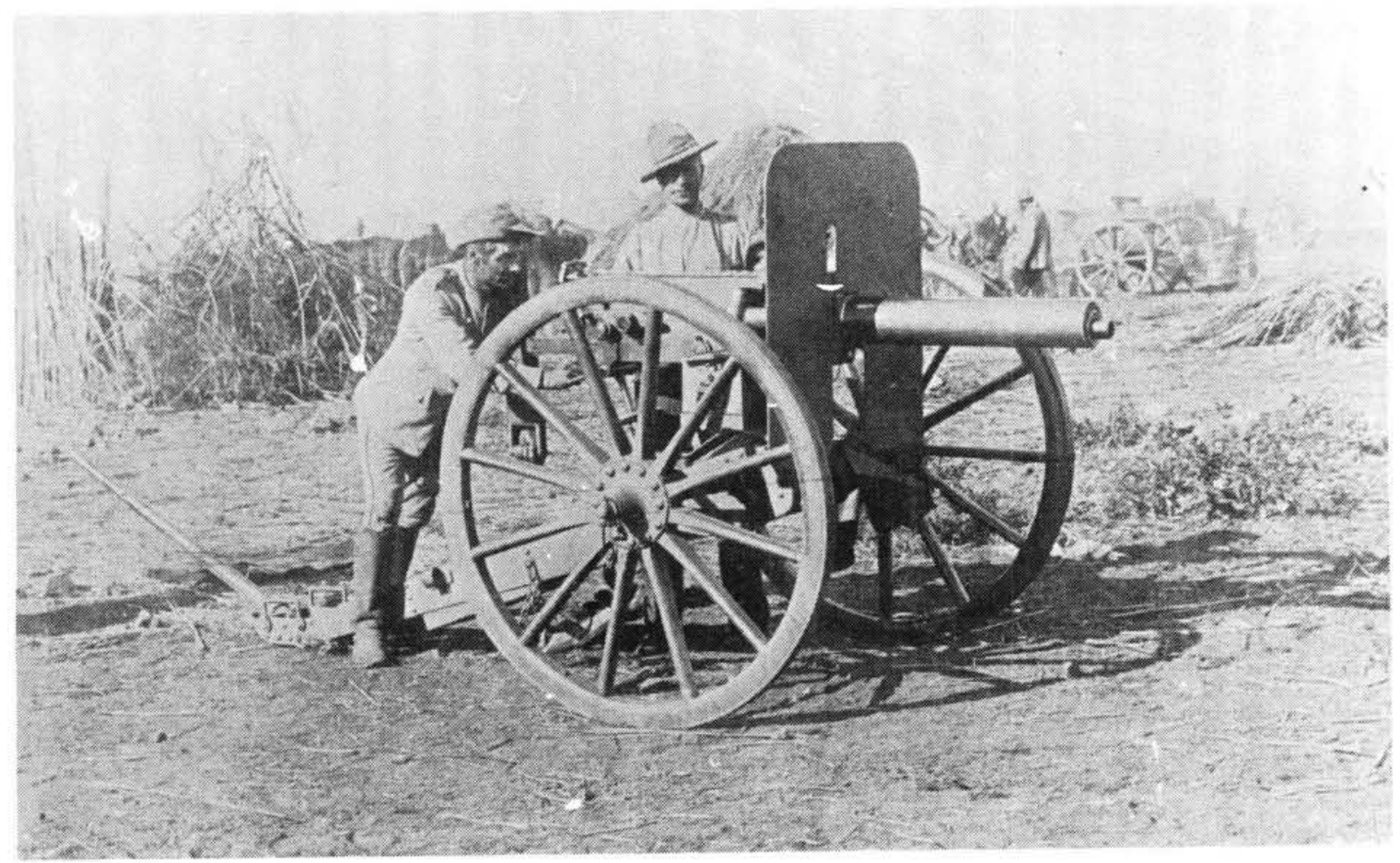

Twee Boere by 'n Pom-pom kanon.

die Unie op te stel, het min mense die verloop van sake met groter belangstelling as genl Beyers gevolg.

Tydens die bespreking van die verdedigingsvraagstuk op die Imperiale konferensie van 1911, was die algemene gevoel dat die Unie sover moontlik sy eie verdediging moes voorsien en dat militêre diens op ' $n$ nasionale basis geplaas moet word.

J.X. Merriman het in Julie 1911 uit Londen aan Smuts geskryf dat hy sou moes besluit hoeveel hy bereid was om op verdediging te bestee en daarvolgens bepaal watter soort staande mag die Unie sou hê. Hy het die konsep wetgewing gekritiseer in soverre algemene opleiding vir gespesialiseerde opleiding plek moes maak en die volk dan glad nie so paraat sou wees nie. Hoewel die land ' $n$ inval sou kon weerstaan, moes hy teen 'n staatsgreep van buite waak.

President M.T. Steyn se kommentaar op die verdedigingswetsontwerp was dat hy teen die lotingstelsel gekant was maar begryp het dat dit weens finansiële oorwegings ingevoer is. $\mathrm{Hy}$ was egter oortuig dat die Republikeinse metode wat elke weerbare man tussen 16 en 23 jaar verplig het om militêre oefeninge te ondergaan, beter was.

\section{Die Verdedigingswet van 1912}

Artikel 1 van die "Suid-Afrika Verdedigingswet" van 1912 het bepaal dat elke burger van sy sewentiende tot en met sy sestigste jaar onderworpe is aan persoonlike diensplig ter verdediging van die Unie en enige deel van Suid-Afrika. Onderworpe aan hierdie voorwaarde kon sodanige burgers ook buite die Unie aangewend word.

Die wet het net voorsiening gemaak vir ' $n$ klein staande mag van sowat 26000 man, (die ZA Berede Schutters), 'n Aktiewe Burgermag wat uit vrywilligers gewerf is en die Kadette. Aangesien daar groot uitgawes aan die konsekwente deurvoering van die beginsel van persoonlike diensplig verbind was, is slegs ' $n$ gedeelte van die toenmalige Aktiewe Burgermag aan 'n militêre opleidingsprogram onderwerp, terwyl die res verplig is om by die Skietverenigings aan te sluit.

Brig-genl C.F. Beyers het die verdediging van die land in 'n ander lig as generaals Botha en Smuts gesien en heelwat kritiek op die wetsontwerp gehad met die indiening daarvan in Februarie 1912. Beyers kon hom nie met die militêre oefeninge vereenselwig soos in die wet bepaal is nie. Sy mening was dat die duur van die oefentyd nie per regulasie moes geskied nie, maar 
volgens wet, waarin 'n vasgestelde aantal dae per jaar neergelê is. Die hele volk moes by oefeninge betrek word. Wat die lotingstelsel betref, het Beyers geglo as daar dwang moes wees, dit algemeen moes word. Beyers was oortuig dat loting ' $n$ verderflike invloed op vaderlandsliefde en persoonlike verantwoordelikheid sou hê. voor bewillig en die mobiele mag van 50000 Suid-Afrikaanse soldate het die Duitse krygsmag in Suidwes-Afrika tot oorgawe gedwing.

In Oktober 1915 het die Unieregering op versoek van die Britse regering 'n mag vir diens in Duits-Oos-Afrika vergader. Gedurende die res

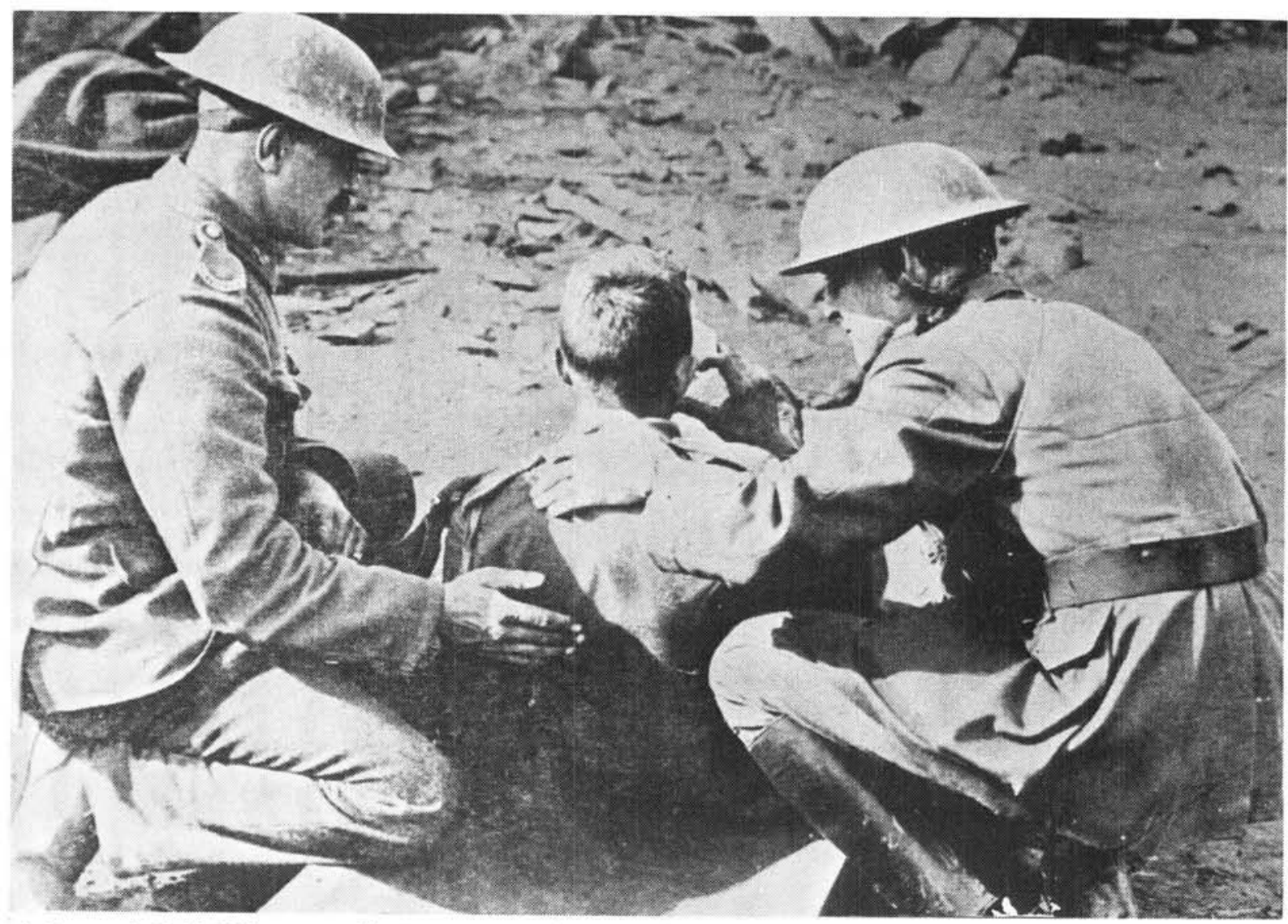

'n Gewonde Suid-Afrikaanse soldaat ontvang aandag van sy kamerade na 'n veldslag op die Westelike Front tydens die Eerste Wêreldoorlog.

\section{Die Eerste Wêreldoorlog}

Die eerste operasionele taak van die Unieverdedigingsmag het met die mynstaking van 1914 aangebreek toe burgers opgeroep is om die krisis wat die land bedreig het, te besleg. Kort na die uitbreek van die Eerste Wêreldoorlog het die Britse regering die Unie versoek om die verdediging van die Britse garnisoen oor te neem. Sonder om die parlement te raadpleeg, het Botha sy samewerking beloof en 'n ekspedisiemag teen die Duitse bewind in Suidwes-Afrika op die been gebring. In 1914 het die Rebellie uitgebreek waarin Afrikaners mekaar die stryd aangesê het oor deelname aan die oorlog al dan nie. Die opstand is deur die regeringstroepe onderdruk en nadat interne vrede bewerkstellig is, kon Botha ' $n$ groot offensief teen die Duitsers loods. Die Parlement het 16 miljoen pond hier- van die oorlog het Suid-Afrikaanse vrywilligers met onderskeiding in Oos- en Noord-Afrika, die Midde-Ooste en Frankryk gedien.

\section{Registrasie vir vredestydse oefeninge}

In 1917 het die Unieregering 'n wet deurgevoer wat militêre oefeninge gedurende vredestyd omskryf het. Dit het voorsiening gemaak vir burgers wat weens oorlogstoestande nie geregistreer was nie. Daar is verdere voorsiening in die wet gemaak vir die vredestydse opleiding van persone wat dienspligtig was, maar tydens die maand van registrasie hul in die buiteland bevind het.

In die jaarverslag van 1924 het die Hoof van die Generale Staf en Sekretaris van Verdediging ge- 
meld dat die Unie in die vorige jaar tov sy verdedigingsorganisasie tot toestande van voor die oorlog teruggekeer het. Die verpligte registrasie van burgers wat die kursus van vredestydse oefeninge vir krygsdiens moes meemaak, is na 10 jaar in Januarie 1924 ooreenkomstig die Verdedigingswysigingswet van 1922 hervat.

Die resultate van hierdie registrasie was hoogs bevredigend aangesien 91,5 persent van die 60504 burgers tussen 17 en 20 jaar wat hulle moes registreer, dit vrywillig gedoen het met die verstandhouding dat hulle vier jaar in die Aktiewe Burgermag sou dien.

Burgers wat in hul een-en-twintigste jaar nie vir vredestydse oefeninge by die Aktiewe Burgermag ingeskryf was nie, sou by die skietverenigings inskakel. Hieruit volg dit dus dat elke burger, tensy hy om een of ander geneeskundige of ander besondere rede vrygestel is, verplig was om oor ' $n$ tydperk van vier jaar, beginnende in sy een-en-twintigste jaar, militêre oefeninge by te woon.
Daar is bevind dat die aanvanklike opleiding van tien dae te kort was omdat daar nie genoeg tyd vir die jong burger was om behoorlik in die beginsels van militêre dril onderrig te word nie.

Vanweë ekonomiese oorwegings was grootskaalse besnoeiings vanaf 1925 aan die orde van die dag as gevolg van die Wysiging op die Verdedigingswet is die "Suid-Afrikaanse Berede Skutters" in 1926 ontbind terwyl die aantal militêre distrikte van vyftien tot ses verminder is. Brig-genl A.J.E. Brink, Hoof van die Generale Staf, het in Junie 1926 sy kommer oor die besnoeiing uitgespreek.

"Expenditure on defence is in the nature of insurance. In the event of serious trouble arising in the future, money spent now will be repaid in hundredfold, whereas money saved at the expense of adequate peace training facilities and precautionary measures is likely to result in enormously increased and avoidable expenditure in any time of emergency."

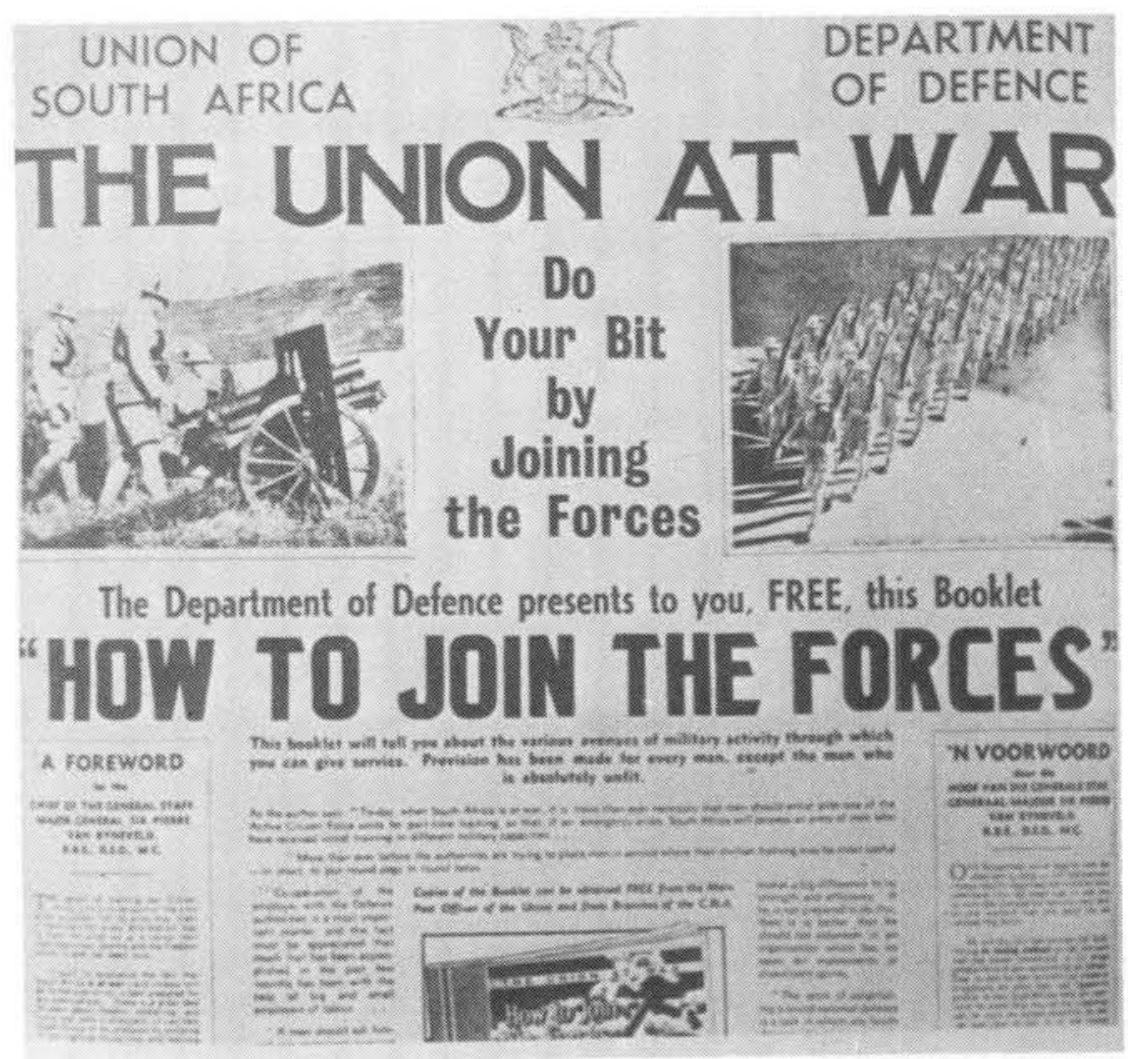

Aan die begin van die Tweede Wêreldoorlog is ' $n$ amptelike brosjure vrygestel waarin alle weerbare mans ingelig is hoe om by die Weermag aan te sluit ingeval van' $n$ algemene oproep 


\section{Tweede Wêreldoorlog}

Hoewel adv Oswald Pirow in sy hoedanigheid as Minister van Verdediging hom reeds sedert 1933 sterk beywer het vir die heropbou van die Unie se krygsmagte, is die uitbreiding en reorganisasie van die verdedigingsmag eers in 1938 aangekondig. ' $n$ Totaal van 5 miljoen pond versprei oor 'n tydperk van drie jaar, is beskikbaar gestel. Voordat hierdie planne uitgevoer kon word, het die Tweede Wêreldoorlog egter uitgebreek. Hierdeur het die sorgwekkende toedrag van sake in die Unieverdedigingsmag veral tov beskikbare opgeleide mannekrag duidelik aan die lig gekom.

Op 16 Februarie 1940 is die Aktiewe Burgermag op die basis van vrywillige diens georganiseer waarvolgens elke soldaat hom daartoe sou verbind om enige plek in Afrika te dien. Dit was die sogenaamde Afrika-Eed wat talle Suid-Afrikaners op grond van hulle politieke oortuigings geweier het om af te lê.

In Maart 1940 is besluit om 'n veldmag bestaande uit die Staande Mag, die Aktiewe Burgermag en twee spesiale berede burgerkommando-brigades op die been te bring. Hoewel die organisasie en opleiding van die veldmag goed gevorder het, was nog rekrute nodig om die Aktiewe Burgermageenhede op oorlogsterkte te bring. Van vrywilligers is verwag om vir die duur van die oorlog te dien.

In Mei 1940 het die Hoofwerwingsoffisier van die Unie aangekondig dat die Verdedigingsmag manskappe vir die Aktiewe Burgermag sowel as vir die eenhede in voltydse diens nodig sou hê. Hy het verklaar: "Die grootste stryd in ons geskiedenis is aangeknoop en ons kan nie net sit en aankyk nie. Ons plek is in die strydperk." Drie divisies is gevorm wat in Oos-Afrika, NoordAfrika, Madagaskar en Italië gedien het.

Weerstand aan die kant van werkgewers was aan die orde van die dag. Die regering het werkgewers gewaarsku dat hulle, volgens bewering, in sommige gevalle onwettig gehandel het deur hul werknemers te waarsku dat hulle hul betrekkings in gevaar sou stel deur of vir voltydse diens of vir diens in die Aktiewe Burgermag aan te sluit. Die regering het verklaar dat sou enige werkgewer 'n werknemer wat militêre diens kragtens die Verdedigingswet van 1912 onderneem, penaliseer, sou die werkgewer swaar gestraf word.

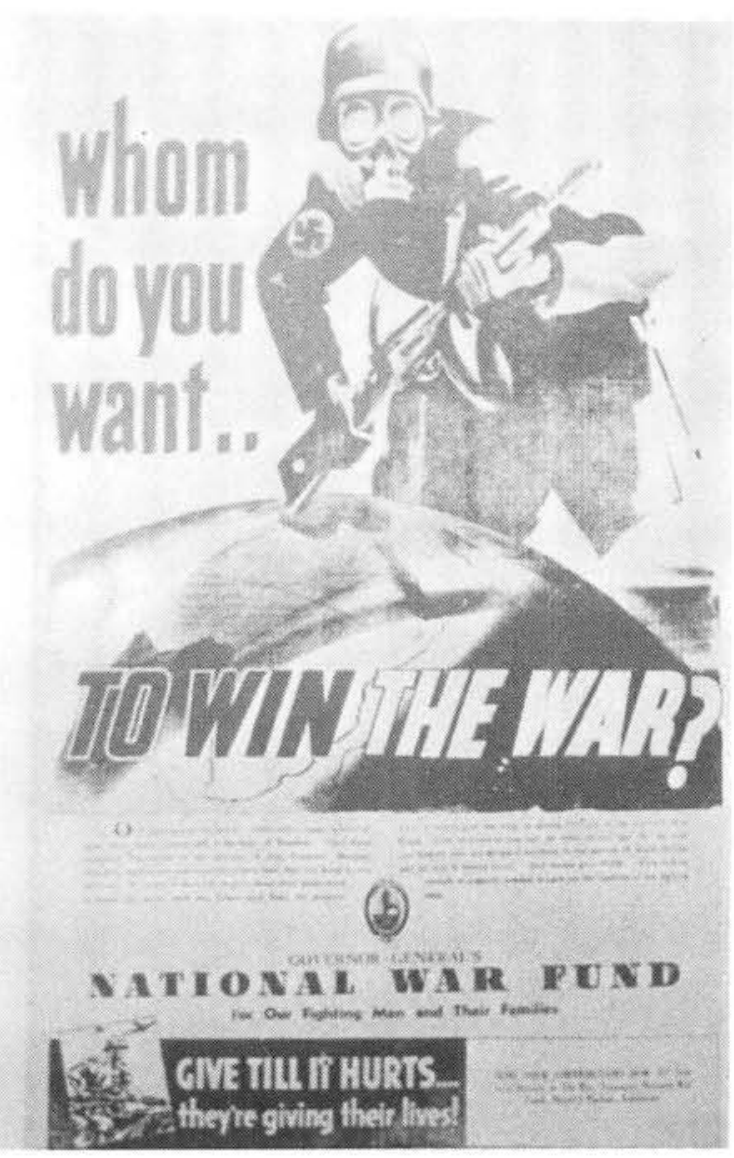

'n Nasionale oorlogsfonds is deur die regering gestig vir Suid-Afrikaners wat aan die Tweede Wêreldoorlog deelgeneem het.

\section{Periode van heropbou: lotingstelsel}

$\mathrm{Na}$ die oorlog het ' $\mathrm{n}$ periode van heropbou en ontwikkeling in die verdedigingsmag gevolg wat ongekend in hierdie land was. Vir die Aktiewe Burgermag wat voorheen sy lede op vrywillige basis opgeroep het, is die lotingstelsel ingestel. 'n Burger wat geregistreer was vir militêre opleiding en wie se naam getrek is, was verplig om diens te ondergaan.

Elke burger moes hom vir militêre opleiding laat inskryf gedurende die jaar waarin hy 16 word. Suid-Afrikaanse burgers oorsee moes hulle binne 30 dae na terugkeer in die Republiek laat registreer en genaturaliseerde burgers in die ouderdomsgroep 17-25 jaar binne 30 dae na naturalisasie.

Almal is in die paar jaar van registrasie geloot en kon nie soos vroeër uitstel van loting kry nie, maar lotelinge kon na loting om uitstel of vrystelling van opleiding aansoek doen. Burgers wat nie vir militêre opleiding opgeroep is nie, kon nogtans aansoek doen om vrywillig opleiding te ontvang. 
Elke burger wat opleiding ontvang het, hetsy vir die Burgermag of in die Kommando's, was onderworpe aan die voorgeskrewe aantal diensjare wat afsonderlik vir die Burgermag of Kommando's bepaal is. Nadat hy sy voorgeskrewe aantal jare diensplig voltooi het, is hy op die Reserwe geplaas. Burgers wat geen opleiding ontvang het nie, het deel van die Nasionale Reserwe gevorm totdat hulle 65 jaar oud was.

\section{Wet 44 van 1957}

Van algemene belang vir die Verdedigingsmag was die nuwe Verdedigingswet no 44 van 1957. Van die belangrikste voorwaardes hier was die insluiting van die Kommando's in die Suid-Afrikaanse Weermag en die Reserwes. Die 1957 Wet het die volgende behels: naamlik dat lede van die kommando's tot militêre diens in oorlogstyd of tydens binnelandse onluste verplig is. 'n Persoon wat in die Unie woon, maar nie 'n burger was nie, kon homself vrywillig verbind om as lid van 'n kommando te dien.

Hoewel die Verdedigingswet van 1957 (no 44) voorsiening gemaak het vir verpligte diens in die kommando's, was laasgenoemde ' $n$ vrywillige organisasie.
In 1958 het die kommando's ' $n$ volwaardige deel van die Suid-Afrikaanse Weermag geword. Soos tans ook die geval is, was elke kommando ' $n$ gebiedsmag, bestem om sy eie afgebakende gebied in tyd van onrus te beskerm.

\section{Wysigingswette van 1961}

Wet 12 van 1961 het voorsiening gemaak vir die aanwending deur die Minister, van lede van die Burgermag en die kommando's gedurende hulle opleiding vir diens ter verdediging van die Republiek of onderdrukking van binnelandse onluste.

Die ononderbroke opleidingsperiode van die Burgermag is deur Wet 42 van 1961 verhoog van 3 maande per jaar met ' $n$ maksimum van nege maande oor ' $n$ tydperk van vier jaar, na ' $n$ maksimum van 9 maande in die eerste jaar plus drie weke in elke daaropvolgende jaar. Die ononderbroke opleiding wat 26 dae oor ' $n$ tydperk van 4 jaar beloop het, is verminder tot ses dae per jaar.

\section{Wet 85 van 1967}

Dit het gaandeweg duidelik geword dat die bestaande stelsels vanweë veranderde omstandig-

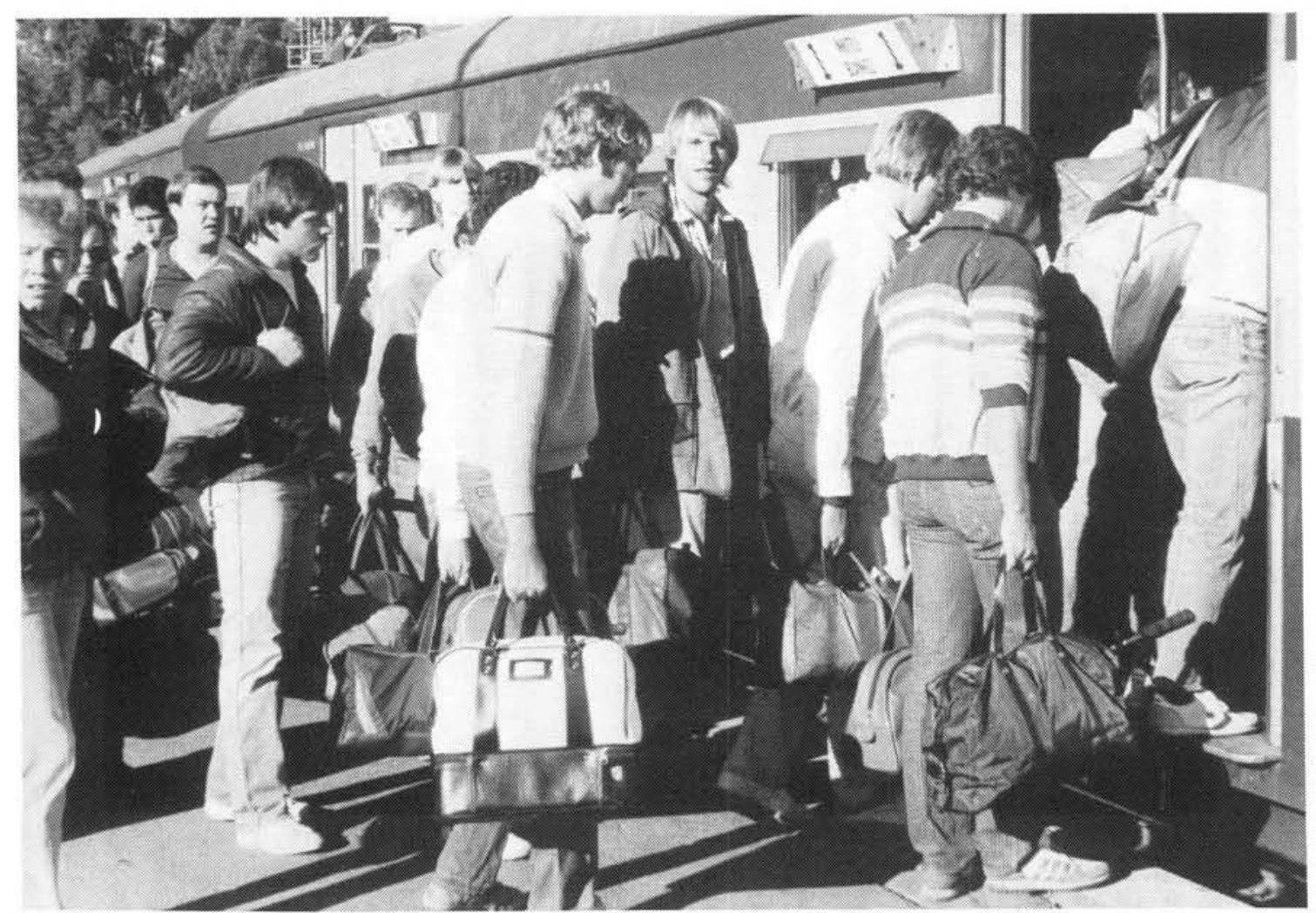

'n Nuwe inname dienspligtiges vertrek per trein na Voortrekkerhoogte om daar vir diensplig aan te meld 
hede opgeknap en hersien moes word. Wet 85 van 1967 wat die Verdedigingswet van 1957 gewysig het, het ingrypende veranderings in die dienspligstelsel aangebring. Daarkragtens is opleiding in diens verander en vreemdelinge kon na 5 jaar se verblyf in die Republiek by die dienspligstelsel betrek word. Die ouderomsbeperking is van 60 na 65 jaar verhoog en 'n kommandoreserwe in die lewe geroep.

\section{Die ingrypendste verandering was naamlik:}

- Diens in die Burgermag is van 4 na 10 jaar verleng en ononderbroke opleiding van hoogstens 9 maande na hoogstens 15 maande plus drie tydperke van 26 dae en vyf van 12 dae met 'n maksimum van 16 maande altesaam. Ononderbroke diens is van ses na drie dae per jaar verminder.

- Verpligte diens in die kommando's is verleng van vier na 16 jaar. Diens in die eerste jaar is vermeerder na hoogstens 60 dae plus 19 dae in elke daaropvolgende jaar.

- Die ou lotingstelsel het verval en jaarlikse keurlyste het in die plek daarvan gekom. Alle dienspligtiges was verplig tot diens in of die Burgermag of die Kommando's.

Die belangrikste verskil tussen die ou en die nuwe stelsel het daarin gelê dat diensplig voortaan as ' $n$ plig en voorreg van elke medies geskikte jong blanke burger van die RSA beskou is en nie meer op ' $n$ persentasie of lotingsgrondslag berus het nie. Nie-burgers van die RSA wat reeds vyf jaar in die Republiek gewoon het en burgerskap wou aanneem, kon ook nou militêre diensplig verrig.

\section{Die kommandomag in die vroeë sewentigerjare}

Wet 28 van 1970 het diens van Kommandolede in die eerste jaar van 60 na 90 dae verleng met 'n totaal van hoogstens 345 dae oor 'n tydperk van 16 jaar.

Om die kommando's beter voor te berei vir die taak van verdediging in hul territoriale gebied, is die opleiding van kommandolede sedert 1972 in lyn met die van die Burgermag gebring. Hulle aanvanklike tydperk van opleiding is tot 9 maande verleng met die gevolglike vermindering van die globale dienspligtydperk van 16 na 10 jaar wat in lyn met die Burgermag was. Uitruilbaarheid van dienspligtigheid tussen die Burgermag en die Kommando's was dus nou moontlik.

\section{Burgermag sedert 1973}

Afgesien van 'n gebieds- of kommandomag, was dit nodig om 'n mag vir die snelle aanwending op enige ander plek waar dit nodig mag wees deurlopend onder wapen te hê. Om hieraan te voldoen is die aanvanklike tydperk van opleiding van 1973 met een maand van 9 tot 10 maande verleng.

Met die oog op die verdediging van ons grense is daar voorsiening gemaak dat lede van die Burgermag afgesien van hul normale verpligting, opgeroep kon word om vir 'n tydperk van hoogstens 4 maande spesiale en ononderbroke diens te verrig. In belang van die landsverdediging is die wet ook so gewysig dat sekere professioneel gekwalifiseerde dienspligtiges wat nie in hul professies in die Weermag benodig is nie, by staatsinstansies of semi-staatsinstansies wat ' $n$ verdedigingstaak het, aangewend kon word.

In 1974 is die verpligte dienstermyn van alle dienspligtiges gestandaardiseer. Die aanvanklike opleidings- en dienstydperk was op dié tydstip ' $n$ minimum van een jaar. Elke dienspligtige sou na sy aanvangstydperk van 12 maande, nog 5 opleidingstydperke van 19 dae elk meemaak. Nasionale dienspligtiges kon hul aanvanklike dienstermyn op vrywillige grondslag tot 18 of 24 maande verleng met ' $n$ gepaardgaande vergoeding $\mathrm{nl}$ die kwytskelding van verdere opleidingsverpligtinge plus kontantbonusse.

$\mathrm{Na}$ gelang werkgewers ' $\mathrm{n}$ meer simpatieke houding teenoor werknemers ontwikkel het wat lede van die Burgermag was, kon vrywilligers meer geredelik na vore kom. Vanweë die SA Leër se grensverpligtinge is minder dienspligtiges as voorheen aan die kommando's toegewys.

Teen 1977 het die Burgermag meer as die helfte van die Weermag uitgemaak en die kommando's het meer as 20 persent verteenwoordig saam het die twee Magte verreweg die grootste gedeelte van die totale sterkte van die Weermag uitgemaak. Dit was ' $n$ ware volksweermag, soos trouens ook in die verlede die geval was.

'n Leemte in die Mannekragvoorsieningstelsel was die onbuigsaamheid daarvan. 'n Maksimum tydperk van diensplig is deur die Verdedigingswet voorgeskryf en daar is betoog dat die Minister groter bevoegdheid moes kry om die aanvanklike dienstydperk te kon herbepaal. 


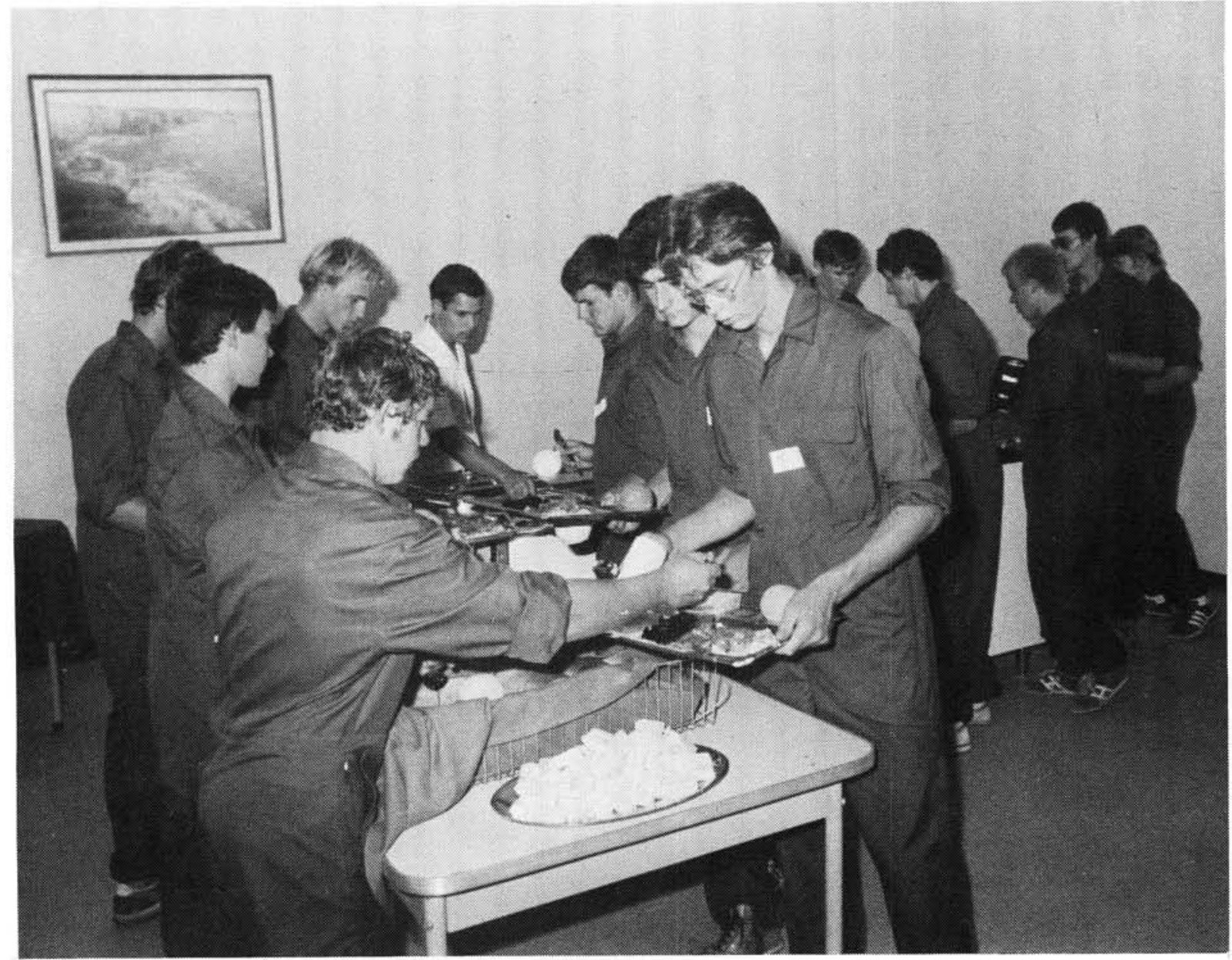

Nuwe aankomelinge kry 'n eerste voorsmaak van wat die volgende twee jaar op hulle wag

\section{Verlengde diensplig - 1977}

Die aanvanklike dienspligtydperk tot 1977 het bestaan uit ' $n$ verpligte dienstermyn van 12 maande waarvan daar 6 tot 9 maande deur opleiding in beslag geneem is. Hieruit was dit duidelik dat die verhouding van opleiding teenoor produktiewe dienslewering nie koste-effektief was nie. Die probleem was dat die SA Weermag en die landsekonomie nie genoeg uit die opleidingsbelegging in die Nasionale dienspligstelsel teruggekry het nie. ' $n$ Verhouding van 8 maande opleiding gevolg deur produktiewe dienslewering van 16 maande was ' $n$ realistieser verhouding en sou meer koste-effektief wees.

Die aanvanklike dienstydperk van alle nasionale dienspligtiges van die Januarie 1977 en latere innames is tot 24 maande verleng. Die stelsel van vrywillige verlengde diens is terselfdertyd gestaak. Dienspligtiges van innames voor 1 Januarie 1977 wat hulle diens vrywillig tot 18 of 24 maande verleng het, is in geen opsig deur die bepaling geraak nie. Diensplig sou vanaf Januarie 197824 maande lank wees en daarna 30 dae op 'n keer.

Na voltooiing van aanvanklike diens moes dienspligtiges vir 240 dae ononderbroke opleiding ondergaan oor ' $n$ periode van 8 jaar wat nie 30 dae op ' $n$ keer moes oorskry nie. Lede was dus net vir ' $n$ totale tydperk van tien jaar aan diensplig onderworpe waarna hulle op die reserwe geplaas is en dan tot op 65 jaar op die betrokke reserwe moes dien.

Die hoofrede vir verlenging van die eerste aaneenlopende dienspligtydperk was om indienstelling van lede van die Burgermag en Kommando's vir tydperke van tot drie maande op ' $n$ keer sover as moontlik te beperk en ten einde ontwrigting wat dit in die ekonomie veroorsaak, te verminder.

Lede wat voor die inwerkingtreding van die 
nuwe dienspligtydperk hul diensverpligting nagekom het (5 kampe of 95 dae), is nie by die nuwe stelsel ingesluit nie en sou op die reserwe geplaas word. Verder is lede wat op 1 Julie 1977 nog nie hulle toentertydse diensverpligtinge nagekom het nie, by die nuwe stelsel ingesluit en sou nie op die reserwe geplaas word nie. Tog het hulle krediet gekry vir diens wat reeds gedoen is.

Volgens die stelsel kon krediet nie vir meer as 30 dae op 'n keer toegestaan word nie, aangesien dienspligtiges net tot 240 dae diens verplig was. Indien hulle vir diensperiodes soos operasionele diens krediet sou ontvang, sou hulle die 240 dae so vinnig afwerk dat hulle nie vir die laaste 3 of 4 jaar van die verpligte 8 jaar beskikbaar sou wees nie. Die Weermag se magspeile sou hierdeur nadelig beïnvloed word en die korpse wat vir operasies benodig word, sou leegloop.

Weens eskalering van die bedreiging het daar nie veel gekom van die voorneme om die Kommandomag en die Burgermag te verminder nie. Wat wel gebeur het, was dat deur die groter beskikbaarheid van Nasionale Dienspligtiges 'n grootskaalse vermeerdering van Burgermag en Kommandomaglede verhoed is.

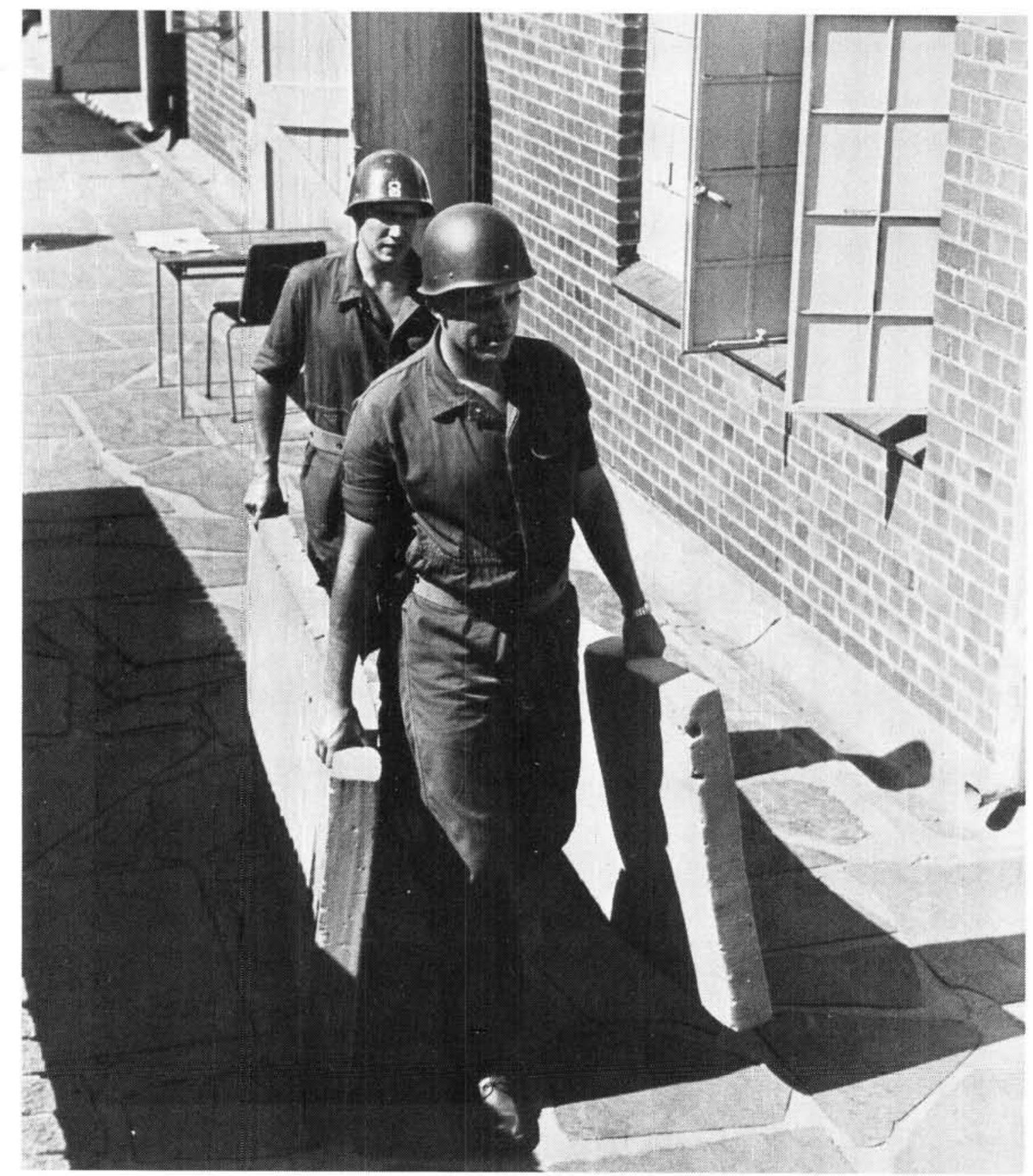

Nuwe inname dlenspligtiges neem hul matrasse in ontvangs 


\section{Ondersoek na diensplig}

Uit ' $n$ studie van die toename in Weermagsterktes in die RSA asook in SWA in die operasionele gebiede was dit duidelik dat troepe skielik met die intensifisering van die bedreiging deurlopend op ' $n$ al hoe groter skaal ontplooi is. Van 1975 tot in 1979 is troepe uitsluitlik in SWA vir operasionele doeleindes en beveiliging van die gebied benodig.

In 1980 is troepe vir die eerste keer in die RSA self vir operasionele doeleindes benodig en sedertdien het die getallesterkte van soldate wat in die operasionele gebiede benodig word steeds toegeneem. Die Weermag se betrokkenheid was elders ook by geïsoleerde gevalle van terroristedade benodig. Hierdie terroristedade het veral in Transvaal, Natal en in Oos-Kaapland voorgekom.

Die Suid-Afrikaanse Weermag is inderdaad ' $n$ volksweermag aangesien die Deeltydse Magte, $\mathrm{nl}$ die Burgermag wat in wese ' $\mathrm{n}$ Reaksiemag is en die Kommandomag of Gebiedsmag die grootste gedeelte van die totale Weermag vorm.

Hieruit kan 'n mens aflei dat indien die toekomstige behoefte aan mannekrag die verwagte en werklike sterkte oorskry die probleem slegs op twee maniere te bowe gekom kan word, $\mathrm{nl}$ deur of die aanvanklike dienspligtydperk te verleng, of 'n beter benuttingsbeleid van die Deeltydse Magte uit te werk.

Aan die einde van 1980 het die Hoof van die Leër 'n projek van stapel gestuur om die heraanpassing van diensplig te ondersoek sodat die land ingeval van 'n grootskaalse konfrontasie paraat sou wees. Die projekspan se opdrag was om ondersoek in te stel na:

(a) Implikasies en probleemoplossings indien alle manlike burgers tot 65 jaar verplig word om onder nie-mobilisasie toestande militêre diens te doen;

(b) Implikasies en probleemoplossings moes bepaal word indien alle manlike burgers wat dienspligtig was en in die toekoms tot militêre diens verplig kon word, tot voortgesette militêre diens tot by bereiking van die ouderdom van 65 verplig word.

(c) Voorts moes ' $n$ stelsel van gedifferensieerde diensplig ondersoek word waarvolgens lede eers teen ' $n$ relatief hoë tempo aangewend kon word. Na gelang hulle ouer word en hulle diensjare aanwas, sou die aanwending verminder.

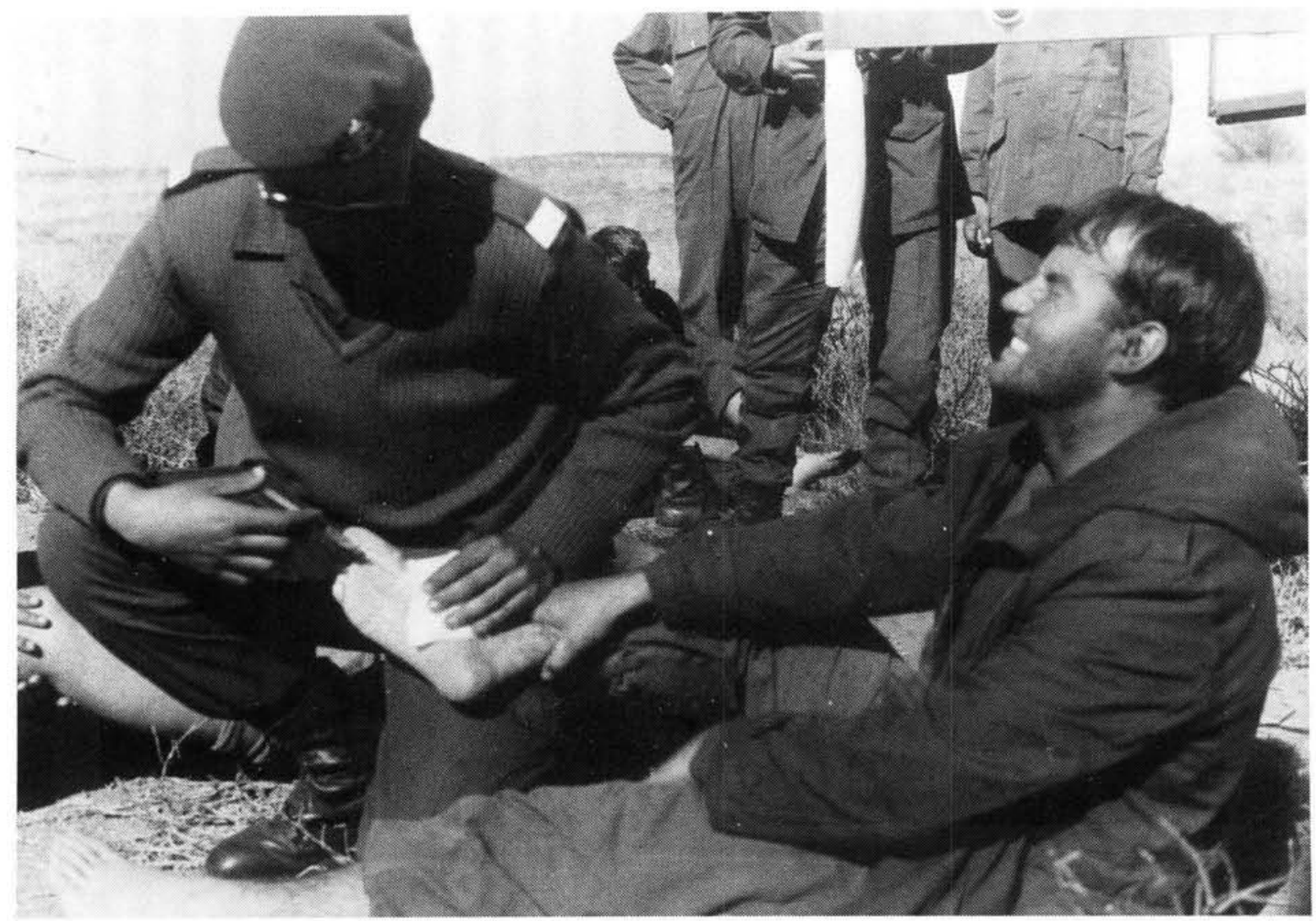

Die seer voete van 'n dienspligtige word behandel tydens 'n uithou-oefening wat deel vorm van basiese opleiding 


\section{Mannekragaanwendingstrategie}

'n Mannekragaanwendingstrategie in die ondersoek na diensplig is na aanleiding van die behoefte aan mannekrag geformuleer. Die teenswoordige en geprojekteerde tekort aan mannekrag vir die tagtigerjare sowel as die bron waaruit dit geput moes word, is in aanmerking geneem. Die kernoorsaak van die behoefte aan 'n omvattende mannekragbeleid is ongetwyfeld die intensifisering van die bedreiging.

Die Weermag sou uiteraard verkies het om die dag-tot-dag operasionele taak met sy voltydse magte te voer en sy deeltydse magte slegs tydens sporadiese opwaartse fluktuasies in vyandelikhede aan te wend. So ' $n$ toedrag van sake sou die land ook die beste te pas kom. Weens die tekort aan mannekrag in die Staande Mag en die Dienspligmag is dit nie moontlik nie.

Vyandelikhede van oor Suidwes-Afrika en die Republiek se noordelike grense is van so ' $n$ aard dat dit die vermoë van die Voltydse Mag ver oorskry. Die Burgermag moet gevolglik ook in hierdie gebiede aangewend word. In sy soeke na 'n oplossing vir die probleem het die Weermag die ontwrigting waaraan lede van die Burgermag blootgestel is om vir lang aaneenlopende tydperke van hul gesinne en persoonlike belange geskei te wees, goed oorweeg. ' $\mathrm{n} \mathrm{Ba}$ lans moes gevind word tussen die koste-effektiewe aanwending van hierdie persone en die ontwrigtende effek wat 'n lang afwesigheid op hulle het.

In 1976 is al besluit om lede van die Burgermag nie langer as drie maande op ' $n$ keer in die operasionele gebied aan te wend nie. Dit beteken dus vyf aflossings per jaar as oorvleueling in berekening gebring word. Weens die ontwrigting daarvan om ' $n$ man jaar na jaar vir 3 maande militêre diens te onttrek, het die Weermag besluit om vir sover moontlik elke man slegs al om die ander jaar vir operasionele diens aan te wend. Dit sou meegebring het dat daar tien man benodig word om ' $n$ deurlopende teenwoordigheid van een te verseker.

Die Weermag se strategie wat die kommandomag betref, is dat hoe groter die ledetal van hierdie mag, hoe meer effektief kan dit optree. Kommandolede word nie vir lang aaneenlopende tydperke van hulle gemeenskapsbelange onttrek nie en daar moet dus voorsiening gemaak word dat hulle mekaar aflos.

\section{Leemtes}

Hoewel die ondersoek op die beskikbaarstelling van voldoende mannekrag gemik was sodat die verwagte eskalasie in vyandelikhede die hoof gebied kan word, is daar ook ondersoek ingestel na metodes om leemtes in die dienspligstelsel reg te stel.

Van die belangrikste leemtes is die volgende:

(a) Die Weermagsverpligting word nie eweredig versprei nie en word slegs deur ' $n$ klein persentasie van die blanke manlike bevolking gedra.

(b) Slegs die normale 30 dae per jaar dienskrediet is toegestaan. Hierdie was 'n demoraliserende faktor wat groot ontevredenheid tot gevolg gehad het.

(c) Die SA Weermag was veral in die Kommandomag tot 'n groot mate van vrywilligers afhanklik. Afgesien daarvan dat hierdie vrywilligers nie tot operasionele diens verplig kon word nie, het hul getalle oor die afgelope jare ook drasties afgeneem. Daar is ' $n$ definitiewe jaarlikse afname in vrywilliger aansluiting wat daarop dui dat die Deeltydse Magte alleen deur ' $n$ vasgestelde diensverpligting genoegsaam beman sal kan word. Vrywilligers is dus allermins ' $n$ gewaarborgde mannekragbron en daarom te riskant om in die huidige veiligheidsituasie op staat te maak.

(d) Werkgewers het met die loop van tyd 'n al hoe groter weerstand teen vrywillige deelname aan militêre aktiwiteite opgebou. Dit het veral ' $n$ negatiewe uitwerking op die beskikbaarheid van senior leiers in die Deeltydse Magte gehad.

\section{Bedreiging}

Onkonvensionele bedreigings waarmee die RSA op die stadium te kampe gehad het, was terroriste aanslae deur sg vryheidsbewegings wat uit basisse in vyandiggesinde buurstate geopereer het en wat deur kommunistiese moondhede gesteun is. Terwyl aansienlike dele van Angola en Noordwes-Mosambiek reeds deur terroriste betree is, word binnelandse onluste deur vyandige en linksgesindes aangehits. Wat die kommunistiese bedreiging betref, hou dit ' $n$ VN aanslag teen Suidwes-Afrika in om die RSA se beheer oor die gebied te beëindig.

Dit het vir die SA Weermag duidelik geword dat die volgende paar jaar krities indien nie deur- 


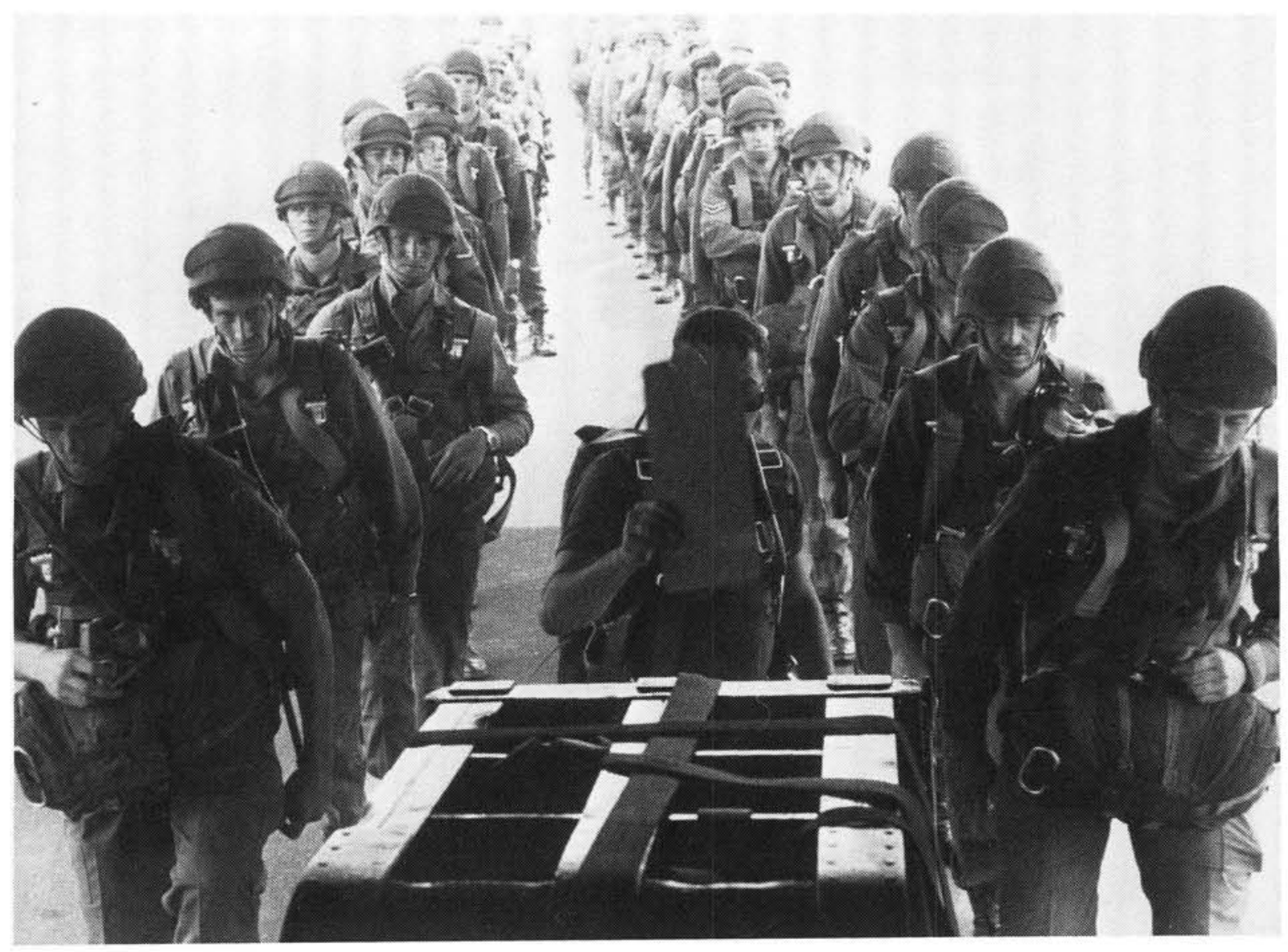

Valskermspringers besig om aan boord van 'n vliegtuig te gaan

slaggewend vir die ordelike voortbestaan van al die inwoners van die Republiek kan wees. 'n Oplossing vir die mannekragprobleem moes dus gevind word. In die verlede kon die land nog altyd staatmaak op mobilisasie om die nodige mannekrag vir 'n oorlogsoperasie te verkry. Nou is die bedreiging egter ' $n$ tipe oorlog wat sonder oorlogsverklaring plaasgevind het. Die uitbouing van die Voltydse Mag sou die ideale oplossing wees. Die groot nadeel hieraan verbonde was egter dat dit sou meebring dat die aanvanklike dienspligtydperk vir blanke mans weer verleng moes word, wat uiters onregverdig teenoor die blanke jong mans sou wees.

\section{Alternatiewe oplossings}

Ander alternatiewe moes dus gevind word. Een so 'n alternatief was om verpligte diensplig na die ander bevolkingsgroepe in die Republiek uit te brei.

Die SA Weermag het dit selfs oorweeg om 'n lotingstelsel vir blanke vroue daar te stel. Daar is bereken dat die eerste lotelinge eers in 1985 opgelei sal kan word as die lotingstelsel in 1982 ingestel kon word. Dié gedagte moes egter in die proses om die wet in die Parlement aangeneem te kry, laat vaar word.

Die alternatief het dus geblyk die aanwending van die Deeltydse Magte te wees tot tyd en wyl die Voltydse Mag tot die vereiste magspeil uitgebou kon word. Nadat daar tot hierdie beslissing geraak is, moes die detail van die toepassing daarvan om aan die voorsiene behoefte te voldoen, uitgewerk word. 


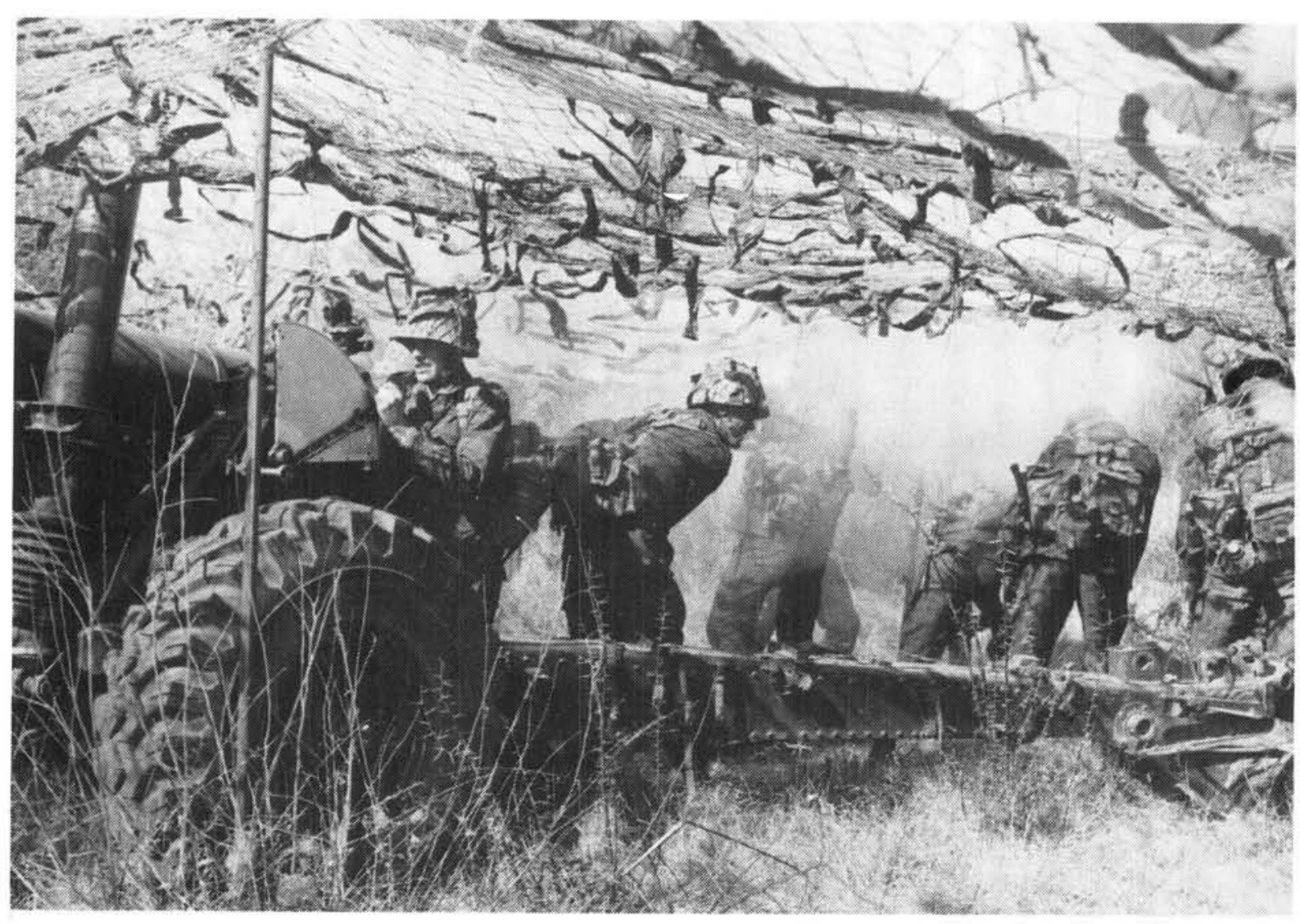

Opleiding van artillerietroepe met die 5.5 kanon

\section{Stadia in die instelling van 'n nuwe dienspligstelsel}

\section{(a) Voorlegging aan die Minister: April 1981}

'n Voorlegging in verband met die wysiging van dienspligtigheid is in April 1981 aan die Minister van Verdediging gedoen. Hierin is voorgestel dat die dienspligtydperk in die Burgermag na 17 jaar verleng moet word maw 2 jaar aaneenlopend aanvanklik en 15 jaar bykomstig of tot by bereiking van 45 -jarige ouderdom. Daarna sou persone nog dienspligtig wees maar wel in die Kommandomag tot op 65-jarige ouderdom en hulle diensverpligting sou 30 dae per jaar wees.

Die voorgestelde verpligting gedurende die 15 jaar Burgermag diens was ' $n$ maksimum van 90 dae per jaar wat afgebroke gedoen kon word. Hierdeur sou voldoende mannekrag beskikbaar wees om die verwagte bedreiging die hoof te bied.

Op versoek van die Minister van Verdediging is verdere ondersoek ingestel met die oog op moontlike verligting van die voorgestelde dienslas in die Burgermag sowel as die Kommando- mag. Met aanvaarding van ' $n$ sekere mate van risiko is daar aan die Minister voorgesel dat die dienstydperk in die Burgermag tot 12 jaar ipv 15 jaar verkort kon word. 'n Reserwemag wat te alle tye georganiseerd en paraat moes wees en waaruit die Burgermag aangevul kon word, sou instand gehou moes word.

Dit is bevind dat die verlaging van die ouderdomsgrens van 65 jaar tot 60 jaar geen noemenswaardige uitwerking op die getalsterktes van die Kommandomag sou hê nie. Verder is besluit om die voorgestelde ouderdomsperk van 45 jaar in die geval van Burgermaglede te laat vaar. Diensverpligting van lede van die Burgermag is bepaal op 120 dae in elke siklus van 2 jaar en die van die Kommandomag op 12 dae per kalenderjaar. Hierdie voorstelle is in beginsel deur die Minister van Verdediging aanvaar en die stelsel kon voorts in detail uitgewerk word.

\section{(b) Konsepwysigingswet}

In Januarie 1982 is volle besonderhede van die nuwe stelsel aan die Kabinet voorgelê waarna dit in 'n konsepwysigingswet vervat is. $\mathrm{Na}$ die 
eerste lesing is hierdie wysigingswetsontwerp na 'n gekose komitee verwys wat die ouderdomsperk van 60 tot 55 jaar gewysig het.

\section{(c) Wet in sy finale vorm}

Op 31 Januarie 1983 het die Wysigingswet op Verdediging 1982 (Wet no 103 van 1982) in werking getree. ' $n$ Wye reeks veranderings in die mannekragvoorsieningstelsel soos van toepassing op die Deeltydse Mag, is hiermee teweeggebring.

Die belangrikste aspekte wat uit die Wet voortgespruit het, was:

- die aanvanklike dienstydperk het nie verander nie;

- die dienstermyn is tot 14 jaar verleng;

- krediet is toegestaan vir elke dag wat diens gelewer is:

- die plasing van lede op verskillende reserwes en die reëlings waarvolgens lede in die konvensionele en gebiedsmagte dien, is ook duidelik uitgespel.

\section{Implementering}

Die riglyne waarvolgens en waarbinne die nuwe dienspligstelsel geïmplementeer moes word, was duidelik:

- 'n Voltydse mag (lede van die Staande Mag en nasionale dienspligtiges tydens hul aanvanklike dienstydperk) word maksimaal uitgebou ten einde die las op die Burgermag soveel moontlik te verlig. Die Voltydse Mag sowel as die Burgermag word as reaksiemagte aangewend binne of buite die landsgrense. Hierteenoor is die Kommandomag ' $n$ gebiedsmag.

- Burgermageenheidsterktes word tot bo die normale eenheidsterkte verhoog om voorsiening te maak vir tekorte wat tydens oproepe kan voorkom. Lede van die Burgermag kan ter wille van hul werks- en huislike omstandighede slegs een jaar van elke tweejaarsiklus vir langer as 30 dae opgeroep word.

- Lede van die Burgermag word nie tydens hul vyfde en sesde siklus sonder persoonlike magtiging van die Hoof van die Weermag en die Minister van Verdediging onderskeidelik opgeroep nie.

- Lede van die Burgermag wat op $31 \mathrm{De}$ sember 1982 reeds 10 jaar daarin gedien het ongeag aantal dae wat hulle gedien het, is

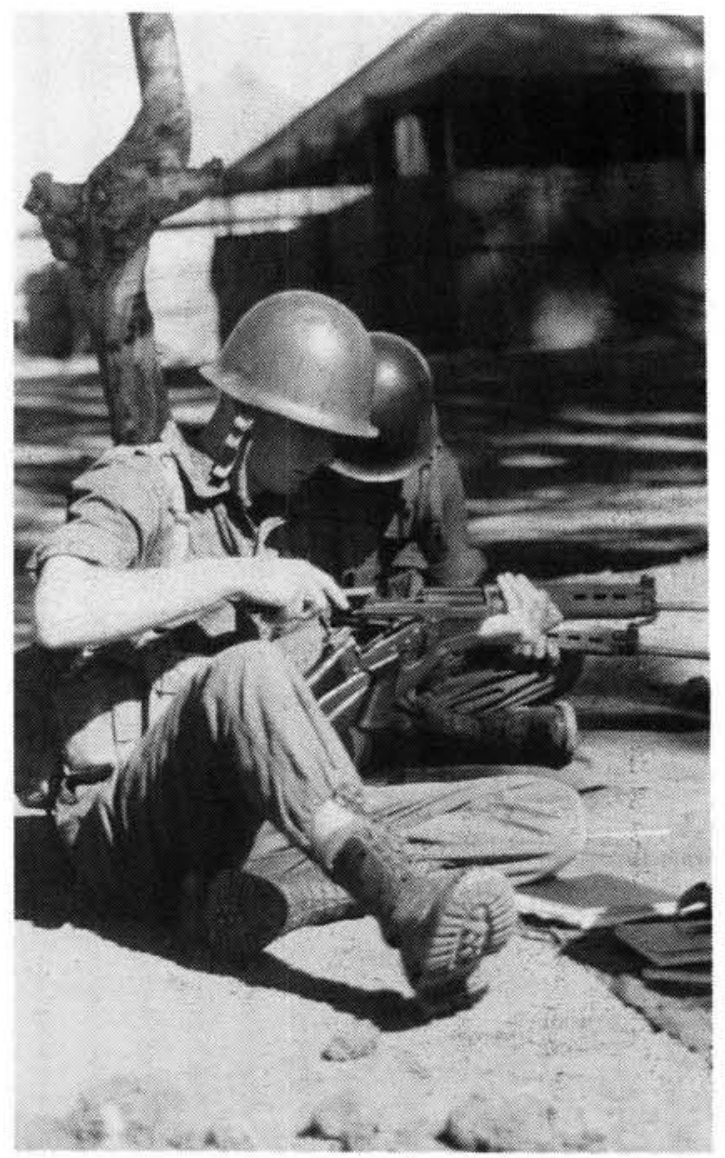

Troepe besig met die skoonmaak en aanmekaarsit van hul gewere tydens basiese opleiding

onthef van verdere verpligte diens in die Burgermag en is oorgeplaas na die Aktiewe Burgermagreserwe. Dit geld ook vir lede wat reeds vier keer 60 dae of langer op 'n keer grensdiens verrig het of wat op daardie stadium nog besig was met ' $n$ vierde grensbeurt.

- Dienste van persone wat op 31 Desember 1982 lede van die Kommandomag was en voldoen het aan die vereistes, is in die Kommandomag behou. Hulle verpligtinge is tot 12 dae per jaar verminder.

- Alle lede van die Deeltydse Mag wat onder die nuwe stelsel nog ' $n$ verpligting gehad het, is van hulle diensverpligting verwittig nadat dit volgens die voorgeskrewe kredietbepalings bereken is.

- Die Staandemagreserwe is hersaamgestel en 'n Aktiewe Burgermagreserwe is gestig waarheen persone wat daarvoor gekwalifiseer het vanaf 1 Januarie 1983 oorgeplaas is. 'n Register van persone wat tot diens verplig is en aan die Kommandomag toegewys kan word, word tans opgestel. Dit sal nog etlike jare duur alvorens die RSA aldus geaktiveer is. 


\section{Leemtes in die nuwe stelsel}

Met inagneming van die wye veld wat die nuwe dienspligstelsel dek, is dit bemoedigend dat so min leemtes en knelpunte in die toepassing daarvan ondervind word. Tog word groot probleme in die stelsel van Kommandodiens ondervind. Die Kommandomag het ' $n$ behoefte aan persone wie se diensplig langer as 12 dae is. Die beskikbare getal gebiedsgebonde lede wat na die Kommandomag oorgeplaas word, is onvoldoende om in hierdie behoefte te voorsien.

Om hierdie probleem reg te stel, word persone met 'n Burgermagverpligting tans aan die Kommando's toegevoeg. Hulle behou egter hul Burgermagverpligting en kan deur die Kommando's vir 'n maksimum van 120 dae in elke siklus van twee jaar aangewend word. Dit skep egter administratiewe probleme aangesien sodanige lede nie volwaardige kommandolede word nie.

\section{Godsdiensbeswaardes}

Die Verdedigingswet maak tans daarvoor voorsiening dat persone wat op bona fide godsdienstige gronde beswaar het teen die verrigting van militêre diens in ' $n$ vegtende hoedanigheid, alternatiewe diens in 'n nie-vegtende hoedanigheid kan verrig.

Hierdie alternatiewe diens maak onder andere daarvoor voorsiening dat gemeenskapsdiens in 'n staatsdepartement, provinsiale administrasie of plaaslike owerheid verrig kan word. Alle besware word oorweeg deur die Raad vir Godsdienstige Beswaar wat op 30 Januarie 1984 deur die Minister van Mannekrag aangekondig is.

\section{Immigrante}

Met die aanvaarding van die Wysigingswet op Suid-Afrikaanse Burgerskap (Wet no 43 van 1984) waardeur die outomatiese verkryging van Suid-Afrikaanse burgerskap bewerkstellig is, is Nasionale Diensplig ook na immigrante uitgebrei.

\section{Drie groepe is hierdeur geraak:}

- Die eerste groep is persone wat in die ouderdomsgroep 15 jaar 6 maande tot 25 jaar val; wat permitte vir blywende vestiging voor 19 April 1978 ontvang het en wat ten minste vyf jaar in die Republiek van Suid-Afrika gebly het.

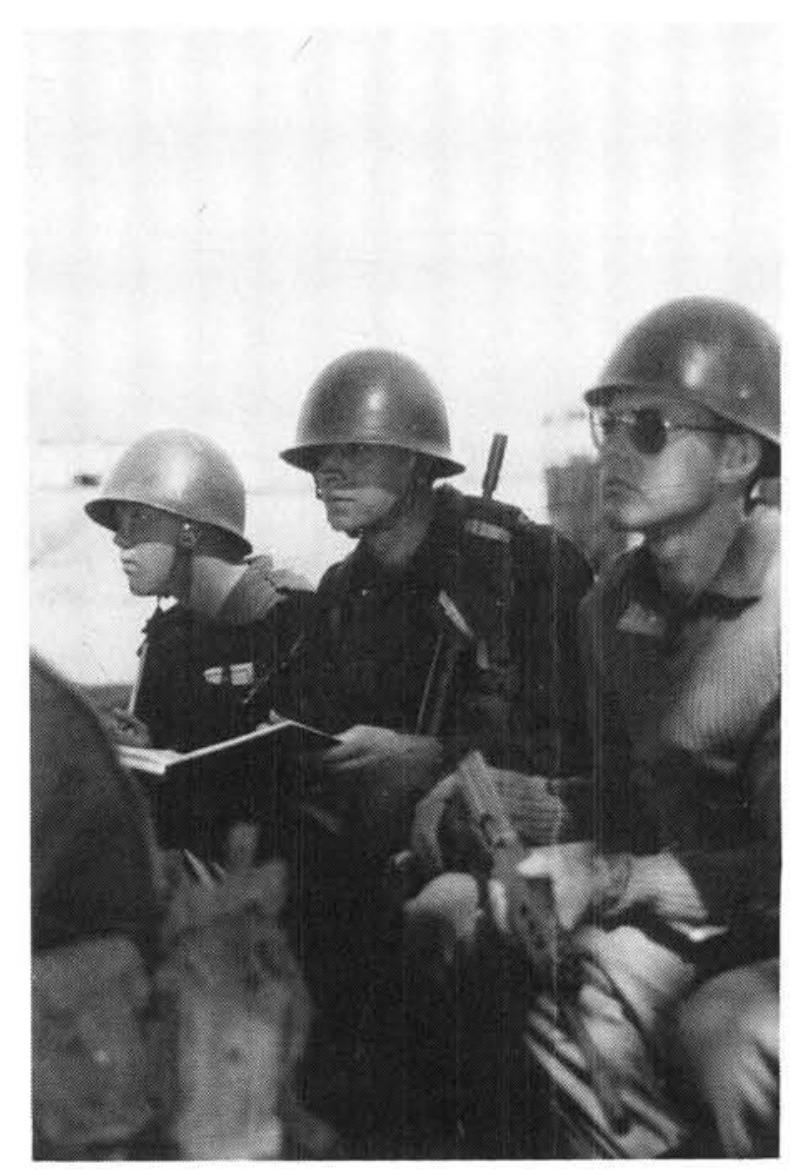

Immigrante troepe van die Julie 1985 inname besig om lesings af te neem tydens basiese opleiding by Klipdrift

- Die tweede groepe is persone aan wie permitte vir blywende vestiging vanaf 19 April 1978 tot en met 10 April 1982 uitgereik is. Persone in die kategorie het voor of op 10 April 1984 outomaties Suid-Afrikaanse burgers geword as hulle op daardie datum nie ouer as 23 was nie en ten minste twee jaar al in die Republiek gewoon het.

- Die derde kategorie is persone aan wie permitte vir blywende vestiging sedert 11 April 1982 uitgereik is. Persone in die groep word outomaties deur naturalisasie Suid-Afrikaanse burgers indien hulle nie jonger as 15 jaar 6 maande en nie ouer as 25 jaar is op die dag waarop hulle vyf jaar lank in Suid-Afrika woonagtig is nie.

Etlike duisende jong immigrante, mans sowel as vroue, word deur die wet geraak. Dit word nie van immigrante wat op of na hul 25 ste verjaardag Suid-Afrikaanse burgers word, verwag om die aanvanklike opleiding van twee jaar en die daaropvolgende Burgermag verpligting na te kom nie. Diesulkes word regstreeks aan die Kommandomag toegewys. 


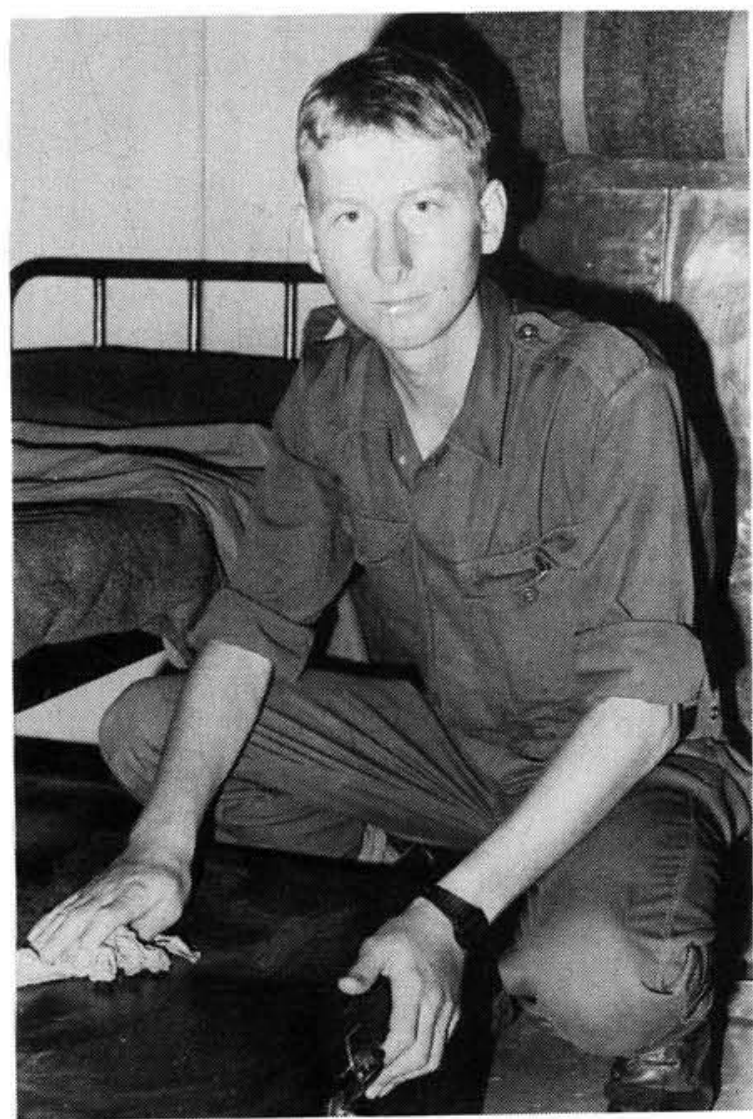

'n Britse immigrant, Christopher Grieves wat sy diensplig by 7 SA Infanterle Battaljon in Phalaborwa doen

Dieselfde reëls wat van toepassing is vir SuidAfrikaners geld vir die immigrante wat vir militêre diens opgeroep word.

* Lt kdr E.M. Meyers MA (HOD) is verbonde aan die Militêre Informasieburo, SAW.

\section{Bibliografie}

A.J. du Plessis, Die Republiek Natalia, Akademiese proefskrif (1939), Universiteit van Stellenbosch, Argiefjaarboek, 1842, deel 1.

W.K. Hancock en J. van der Poel (reds), Selection from the Smuts Papers, Cambridge University Press, 1966.

D.W. Krüger, The Making of a Nation - History of the Union of South Africa 1910-1961, Johannesburg, 1969.

E.M. Meyers, Voorgeskiedenis tot die stigting van 'n Unieverdedigingsmag, Militaria 12/2, 1982.

C.F.J. Muller (red), Vythonderd Jaar Suid-Afrikaanse Geskiedenis, Pretoria, 1968.

J. Ploeger, Op Brandwag - Drie eeue militêre geskiedenis van Suid-Afrika, Militaria 1/4, 1969

P.E. Roux, Die Verdedigingstelsel aan die Kaap onder die Hollands-Oos Indiese Kompanjie (1652-1759), Stellenbosch, 1925.

Sesa vol 7, 1972.

T.P.E. Swemmer, Die Geskiedenis van die Vrystaatse Artillerie, MA-Tesis (1953), Universiteit van Oranje Vrystaat.

G.D. Scholtz, Generaal Christiaan Frederick Beyers 1869-1914, Johannesburg, 1941.

$\mathrm{J}$ van der Poel, Basutoland as a Factor in South African Politics (1858-1870). MA-Tesis (1925), Universiteit van Kaapstad, Argiefjaarboek, 1941, deel 1 .

F.A. van Jaarsveld, Die Veldkornet en sy aandeel in die opbou van die SuidAfrikaanse Republiek tot 1870, MA-Tesis (1946), Universiteit van Pretoria, Argiefjaarboek, 1950, deel II.

A.J.H. van der Walt, ea (reds), Geskiedenis van Suid-Afrika, deel I, Kaapstad 1951.

Volkstem, 24.5.1940.

Volkstem, 18.5.1940

Oorsig oor Verdediging en Krygstuigproduksie - Tydperk 1960 tot 1970.

Witskrit oor Verdediging, 1973

Witskrit oor Verdediging, 1975

Witskrif oor Verdediging, 1977

Witskrif oor Verdediging, 1979.

\section{Saw-argief}

Argiefgroep CGS, Groep 2, Houer 46, Lêer 38: Annual Report 1923 - 1924. Argiefgroep CGS, Groep 2, Houer 398, Lêer 530/6: CG + ACF Training 1928-29 - Non Continuous Training.

Argiefgroep CGS, Groep 2, Houer 198, Lêer 329/47: D.R. Associations Organization and Instructions - Training of Mounted Brigades.

Argief CGS, Groep 2, Houer 586, Lêer 1019/0/3: Training of PF and ACF Standing Instructions, Notices to Employers.

Argiefgroep DC 786, Houer 2452, Lêer 1075/1: Kommando's.

Argiefgroep DC, Groep 332, Lêer 35199: Special Provisions Act 1917 Registration for Peace Training.

Pamflet 1818, Houer 95, Publikasies 102: Kort geskiedenis van die SAW. Pamflet 1824, Pubs 99: A Proud Military Tradition.

Pamflet 3120, Houer 99: The History of the South African Defence Force. 